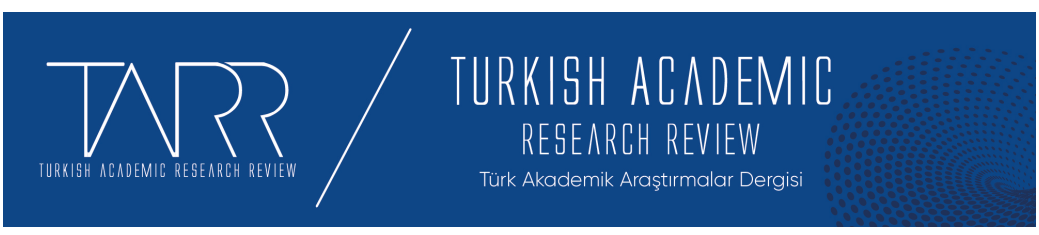

e-ISSN: 2602-2923 Yıl/Year: 2021 Cilt/Volume: 6 Sayı/Issue: 5

\title{
İsrâiloğullarıyla İlgili İki Âyet Grubunun (Bakara Sûresi 40-44 ve 67-73) Kur'ân'ın İletişim Üslûbu Açısından İncelenmesi
}

An Investigation of The Two Verse Groups Related to The Israelites (Surah al-Baqarah 40-44 and 67-73) in Terms of The Qur'an's Communication

Style

\section{Murat ÖZOKUDAN - Eyüp YAKA}

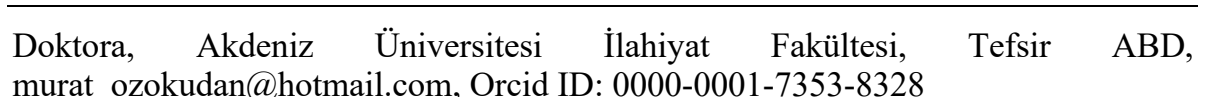
murat_ozokudan@hotmail.com, Orcid ID: 0000-0001-7353-8328

Dr. Öğr. Üyesi, Akdeniz Üniversitesi İlahiyat Fakültesi, eyaka@akdeniz.edu.tr, Orcid ID: 0000-0002-6790-7016

\begin{tabular}{r|l} 
Makale Bilgisi & Article Information \\
Makale Türü - Article Type & Araştırma Makalesi / Research Article \\
Geliş Tarihi - Date Received & $30 \mathrm{Kasım} /$ November2021 \\
Kabul Tarihi - Date Accepted & 28Aralık/ December2021 \\
Yayın Tarihi - Date Published & 31Aralık/ December2021 \\
Yayın Sezonu & Aralık \\
Pub Date Season & December
\end{tabular}

Atıf/Cite as: Özokudan, M.-Yaka, E., (2021),İsrâiloğullarıyla İlgili İki Âyet Grubunun (Bakara Sûresi 40-44 ve 67-73) Kur'ân'ın İletişim Üslûbu Açısından İncelenmesi/ An Investigation of The Two Verse Groups Related to The Israelites (Surah al-Baqarah 40-44 and 67-73) in Terms of The Qur'an's Communication Style .Turkish Academic Research Review, 6 (5), 1648-1671. Retrieved from https://dergipark.org.tr/tr/pub/tarr/issue/67845/1030718

Intihal /Plagiarism: Bu makale, en az iki hakem tarafından incelenmiş ve intihal içermediği teyit edilmiştir. / This article has been reviewed by at least two referees and confirmed to include no plagiarism. https://dergipark.org.tr/tr/pub/tarr

Copyright (C) Published by Mehmet ŞAHIN Since 2016- Akdeniz University, Faculty of Theology, Antalya, 07058 Turkey. All rights reserved.

Turkish Academic Research Review - Türk Akademik Araştırmalar Dergisi 


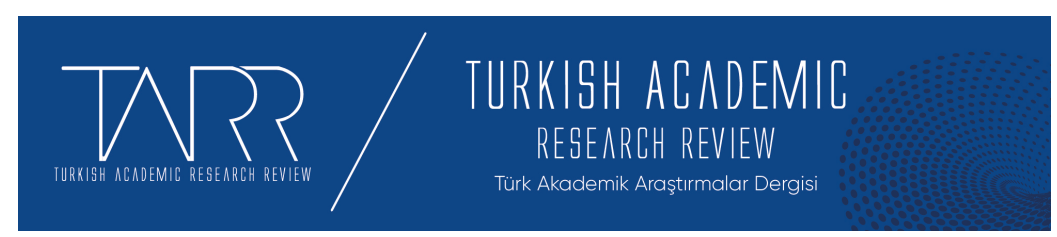

e-ISSN: 2602-2923 Yll/Year: 2021 Cilt/Volume: 6 Sayı/Issue: 5

\title{
İsrâiloğullarıyla İlgili İki Âyet Grubunun (Bakara Sûresi 40-44 ve 67-73) Kur'ân'ın İletişim Üslûbu Açısından İncelenmesi*
}

\author{
Murat ÖZOKUDAN - Eyüp YAKA
}

$\ddot{O} z$

Yüce Allah, insanlara iletmek istediği mesajları vahiy yoluyla ve yine insanlardan seçtiği elçileri vasıtasıyla bildirmiştir. Bu bakımdan Kur'ân, ontolojik açıdan farklı iki varlık arasında cereyan eden bir iletişimdir. Bilgilerin, düşüncelerin ve duyguların anlamlarında uzlaşılmış simgeler aracılığıyla biriktirilip aktarılması şeklinde tanımlanan iletişim kavramı, çeşitli unsurların etkili olduğu, sistemli yürütülmesi gereken, kimi zaman ise öngörülemez ve kaçınılmaz olan kompleks bir süreci ifade etmektedir. Nüzul döneminde itikâdî, sosyo-kültürel ve ekonomik açıdan farklı insan gruplarına seslenen Kur'ân, muhatabının mizacını, karakterini ve psikolojik durumunu göz önünde bulundurarak kaotik bir görüntü arz etmeyecek şekilde pek çok metot kullanmıştır. Kur'ân'ın hitâp ettiği gruplardan biri olan İsrâiloğulları; inatçı tabiatları, kelimeleri bağlamından koparma alışkanlıkları (tahrif) ve kalplerinin katılığı ile tebarüz etmişlerdir. Bu bağlamda İsrâiloğullarıyla ilgili ayetlerin iletişim odaklı incelenmesi, Kur'ân'ın ferdi (kendine özgü) iletişim üslûbunu ortaya koymada yardımcı olacak önemli bir çalışma olarak görünmektedir. $\mathrm{Bu}$ makalede, söz konusu iki ayet grubunun satır aralarından elde edilen veriler analiz edilerek Kur'ân'ın iletişim üslûbuna dair kısmi bir tasavvur oluşturulması amaçlanmıştır. Mezkûr amaç doğrultusunda öncelikle Kur'ân'ın mahiyetine dair bilgiler verilmiş, İsrîailoğulları'nın Kur'ân'da yer alan karakteristik özellikleri ele alınmış; sonrasında ise araştırma konusu olan ayetlerde bulunan üslûp enstrümanları tespit edilerek bunların Kur'ân'ın bütünüyle olan irtibatı kurulmaya çalışılmıştır. Söz konusu ayet grublarının incelenmesi neticesinde muhataba saygı duyma, muhatabın dikkatini çekme, mesajın muhatabı etkileyecek şekilde sunulması, akıl ve duyguların bileşkesi şeklinde yaratılan muhatabın (insanın) hem aklına hem de gönlüne hitap etme gibi ilke ve metotlar Kur'ân'ın iletişim üslubunun mümeyyiz vasıfları olarak ön plana çıkmaktadır. Üslûbü'l-Kur'ân içerisinde dengeli bir şekilde yer alan bu ilke ve metotlar yüce Allah'ın insanla kurduğu iletişime verdiği değeri de yansıtmaktadır. Muhatap konumunda olan insan ne kadar inatçı ve ön yargılı olsa da yüce Allah çeşitli metotlar kullanarak onun dikkatini çekmiş ve iletişim ortamının akamete uğramasına izin vermemiştir.

Anahtar Kelimeler: Tefsir, Kur’ân, İletişim, Üslûp, İsrâiloğulları.

* Bu makale "Bakara Sûresi Bağlamında Kur'ân-1 Kerim'deki İletişim Esasları" adlı yüksek lisans tezi esas alınarak hazırlanmıştır.

Turkish Academic Research Review - Türk Akademik Araştırmalar Dergisi 


\title{
An Investigation of The Two Verse Groups Related to The Israelites (Surah al-Baqarah 40-44 and 67-73) in Terms of The Qur'an's Communication Style
}

\begin{abstract}
Almighty Allah conveyed the messages he wanted to convey to people through revelation and again through the messengers he chose from people. In this respect, the Qur'an is a communication that takes place between two ontologically different beings. The concept of communication, which is defined as the collection and transfer of information, thoughts and feelings through symbols, is among the basic parameters that direct the lives of human beings. Addressing different groups of people in terms of beliefs, socio-cultural and economic terms during the revelation period, the Qur'an used many methods in a way that does not present a chaotic appearance, taking into account the temperament, character and psychological state of its addressee. Israelites, one of the groups addressed by the Qur'an; They are distinguished by their stubborn nature, their habit of breaking words out of context, and the rigidity of their hearts. In this context, the communication-oriented examination of the verses about the Israelites appears to be an important study that will help to reveal the individual (unique) communication style of the Qur'an. In this study, we aimed to create a vision of the communication style of the Qur'an by analyzing the data we obtained between the two verse groups in question. In line with the aforementioned purpose, firstly, the stylistic elements included in the verses that are the subject of research were determined, and then they were tried to be contacted with the whole of the Quran. As a result of the examination of the verse groups in question, principles and methods such as respecting the addressee, attracting the attention of the addressee, presenting the message in a way that will affect the addressee, appealing to both the mind and the heart of the addressee (human), created as a result of the mind and emotions, are the distinctive features of the Qur'an's communication style.
\end{abstract}

Keywords: Exegesis, Qur'an, Communication, Style, Israelites.

\section{Structured Abstract}

Communication which is sometimes unpredictable and inevitable and in which many factors are effective is a complex process that must be carried out systematically. In order for this process to be completed successfully, different methods and applications should be put into use. Because the human factor, which is the backbone of communication, has an intricate structure and varies in terms of temperament and character. While it is easier to communicate with mild-tempered people, it may be somewhat more difficult to communicate with someone with a harsh temperament. The mass of people accepted by the Qur'an during the Nüzul Period does not display a homogeneous image and in this period there are different groups in terms of belief system and socio-cultural aspects. One of these groups, the Israelites, who occupy a large place in the Qur'an, come to the fore with their stubborn attitudes and distortions of words. In this context, examining the communication of both the prophets and the Almighty Allah with this belief group

Turkish Academic Research Review - Türk Akademik Araştırmalar Dergisi 
seems to be an important study that needs to be done in order to have an idea about the communication style of the Qur'an.

While both Prophet Moses and the Almighty Allah were addressing this people, they made them feel that they had an independent and free personality, and they communicated accordingly. The fact that Almighty Allah calls out to them with suggestions and warnings, not compulsorily, and wishes them to carry out their character transformations with their own preferences indicates that a healthy communication can only occur between single entity.

How is a healthy communication established despite the fact that God and human-being are ontologically two different entities? Nasr Hamid Ebu Zeyd answered this question, "There has been a transformation in one of the parts that allows communication with the other part. In other words, The Prophet Mohammad (pbuh) took the form of an angel by getting rid of his human form, or the angel took the form of a human." replied in the form. However, this answer ignores the content part of the message and the part related to the textual structure. How does the Divine Word, which is transcendent, address the level of human comprehension? The Qur'an embodies the abstract issues that require intense thought, especially in the metaphysical field, with the method of representation, and presented them to the individual's understanding. Thus, one of the most important phases of communication, "organizing and coding the content of the message", was completed and the groundwork for a healthy communication was prepared. It is also discussed whether Almighty Allah's address to human beings can be considered as a real communication because Almighty Allah directs some warnings, orders and advices to human-being. On the other hand, mankind does not have any verbal response. Therefore, it is assumed in the Qur'an that God's address to man is a one-sided message rather than a full communication. However, communication is not just about verbal messages and feedback. If the message sent from the source prompts the addressee to take a stand and exhibit an attitude, this situation enters the field of the meaning of the concept of communication.

The Prophet Moses' communicating with the Israelites, the insincerity of this belief group towards communicating and their lack of respect for the addressee are observed. In order for the communication to be concluded successfully without fail, the parts should aim to communicate in real terms and respect each other to the maximum extent. With the questions they asked as a manifestation of their insincerity, the Israelites narrowed a large area for them and made it difficult for the expected benefit from communication to be achieved.

One of the distinctive features of the Qur'an's communication style is that it starts with an impressive expression that will attract the attention of the addressee and keeps the attention of the addressee alive throughout the communication. Both the way in which the Prophet Moses began to speak with an expression that would arouse the desire to learn the continuation of the speech in the audience, and the way of the Almighty Allah addressing to the Israelites points to the stylistic feature of the Qur'an. In order to achieve the aim of "creating desired behaviors in the interlocutor", which is the most important purpose of communication, it is not enough to attract the attention of the addressee only at the beginning; at the same time, the content of the message and the way it is presented must influence it. For this purpose, the Qur'an has emphasized the mind-heart dialectic, which is the decision-making mechanism of human beings, and has revealed the importance of 
the heart and emotions in interpersonal relations with the combination of "thinking heart".

\section{Giriş}

İnsanoğlunun hayatını şekillendirmesinde önemli pay sahibi olan iletişim olgusu hakkında pek çok tanım yapılmakla birlikte kapsayıcı olması açısından genel bir ifade ile iletişimi "Bilgilerin, düşüncelerin ve duyguların anlamlarında uzlaşılmış simgeler aracılığıyla biriktirilip aktarılmasının ve alışverişinin hem ortak hem de değişik zaman ve mekân boyutlarında gerçekleştirilmesi” şeklinde tanımlayabilmek mümkündür. ${ }^{1}$ Bireyin hem yatay (kişiler arası) hem de dikey (Allah ve kul) anlamda taraf olduğu iletişim, onun tutum ve davranışlarına yön veren değer sisteminin oluşmasında etkin rol oynayan temel parametrelerdendir. ${ }^{2}$ Dikey iletişim çeşidiyle ilgili olarak Kur'ân'da yüce Allah'ın bir insanla konuşmasının ancak vahiy yoluyla, perde arkasından veya elçi göndermek suretiyle mümkün olacağı haber verilmektedir. ${ }^{3}$ Çalışmamızda sınırları belirli bir şekilde Kur'ân'ın iletişim üslûbunu irdeleyeceğimizden dolayı bizim için anahtar kelimelerden biri de "vahiy" kavramıdır. Terim olarak "Allah'ın insanlara bildirmek istediği buyrukları, onların arasından seçtiği peygamberlerine insanların alışık olmadığı gizli ve süratli bir yolla bildirmesi" anlamına gelen vahiy kavramı, ${ }^{4}$ Allah ile insan arasında gerçekleșen iletişimi ifade etmektedir. ${ }^{5}$ Vahiy mahsulü olan Kur'ân-1 Kerîm'in iletişim üslûbunu anlayabilmek için öncelikle onun mahiyeti hakkında bazı bilgilere sahip olmak gerekmektedir.

Kur'ân, ontolojik açıdan farklı statülerde bulunan iki varlık arasında cereyan eden bir iletişimdir. ${ }^{6}$ Bu sebeple Kur'ân'ın mahiyeti hakkında bir tasavvura sahip olmak için onu hem mütekelliminin hem de muhatabının mahiyetiyle beraber incelemek gerekmektedir. Kur'ân'ın mütekellimi konumunda olan yüce Allah, ilminin ve kudretinin sınırı olmayan, hata ve kusur gibi eksikliklerle nitelenemeyecek aşkın ve ezeli bir mahiyete sahiptir. Buna karşın muhatap konumunda olan insan ${ }^{7}$ ise bilgi bakımından sınırlı bir kapasiteye sahip olup hata

1 Merih Zillıoğlu, Iletişsim Nedir? (İstanbul: Cem Yay, 2014), 24; Ünsal Oskay, Iletişimin ABC'si (İstanbul: İnkılâp Yayınları, 2016), 23.

2 İletişimin yatay ve dikey şeklinde tasnif edilmesi, mekansal bir anlam çağrıştırması için değil ontolojik farklılığa işaret etmek amaçlıdır.

3 Şûrâ $42 / 51$.

4 Hüseyin b. Mufaddal Râğıb el-İsfehânî, el-Müfredât fí ğarîbi'l-Kur'ân, thk. Safvân Adnan ed-Davudî (Dimeșk: Dâru'l-Kalem, 1412), 859; Muhammed Abdülazîm ez-Zürkânî, Menâhilü'l-irfân fí ulûmi'l-Kur'ân (Matbaatu Îsâ el-Bâbî el-Halebî), I/63; Subhî b. İbrâhîm es-Sâlih, Mebâhis fí ulûmi'l-Kur'ân (Beyrut: Dâru'l-İlmi li'l-Melâyîn, 2014), 25.

5 Nasr Hâmid Ebû Zeyd, Ilahi Hitabın Tabiatı - Metin Anlayışımız ve Kur'an Illimleri Üzerine-, çev. Mehmet Emin Maşalı (Ankara: Otto Yayınları, 2013), 73; Muhsin Demirci, Vahiy Gerçeği (İstanbul: Marmara Üniversitesi İlahiyat Fakültesi Vakfi Yayınları (IFAV), 1996), 237.

6 Nasr Hâmid Ebû Zeyd, Ilahi Hitabın Tabiatı, 64.

7 Kur'an'1 okuyan veya dinleyen her bir birey onun muhatabidir. Hz. Peygamber'in vahiy ile mülaki olması farklı bir bağlamın konusu olup bu noktada Hz. Peygamber'in herhangi bir dahlinin, hata ve kusurunun 
işleme, yanlış anlama ve meramını tam bir şekilde ifade edememe gibi zihinsel ve davranışsal eksikliklerle muallel bir yapıdadır. Yüce Allah'ın gaybı tam anlamıyla bilmesinden ve mutlak bir kudrete sahip olmasından dolayı Kur'ân'da istihbar (bilgilenme) ve talep türü söz çeşitleri yer almamakta; sadece haber, emir ve nehiy çeşitleri bulunmaktadır. ${ }^{8}$ Aynı zamanda Kur'ân söz konusu olduğunda, beşer sözünde bulunması muhtemel olan ve muhatabın hitâbı anlamasına engel teşkil eden tasavvur zaafından veya ibare kusurundan bahsetmek mümkün değildir. ${ }^{9}$ Pekâlâ ontolojik farklılığa rağmen taraflar arasında iletişim nasıl meydana gelmiştir? Aşkın ve ezeli olan Kelâm-1 İlâhî beşer idrakine nasıl sunulmuştur?

Kur’ân, sözlü kültürün yaygın olduğu bir ortamda nazil olmuştur. Vahyin ilk muhatapları yazılı bir metinden daha ziyade hayatların içine alan, betimleyen, sorgulayan, onları yeni bir tutum almaya sevk eden ve yaşayan canlı bir sözle karşılaşmışladır. ${ }^{10}$ Cahiliye toplumunun "ümmi" bir toplum olmas ${ }^{11}$ ve kabileler arası mücadelelerde sözlü hitabın insanlar üzerinde kuvvetli etki meydana getirmesi gibi sebepler sözlü kültürün revaç bulmasına zemin hazırlamıştır. ${ }^{12} \mathrm{Bu}$ sebeplerden dolayı Kur'ân, sözlü anlatım biçimi olan "hazf", "tekrar", "kümeleme anlatım", "insan merkezli anlatım", "mücadeleci anlatım”, "duyguların paylaşımına dayalı anlatım" ve "işlevsel ve somut anlatım" metotlarına üslûbunda yer vermiştir. ${ }^{13}$

Kur'ân'da diğer toplumlara kıyasla haklarında en ayrıntılı bilgilerin yer aldığı kavim olan İsrâiloğulları, kalplerinin katılığıyla ve inatçı karakterleriyle ön plana çıkmaktadır. ${ }^{14}$ Özellikle Bakara Sûresi 40 ile 146. âyetler arasında geniş bir şekilde ele alınan İsrâiloğulları'nın gerek yatay gerekse dikey anlamda taraf oldukları iletişim, Kur'ân'ın iletişim üslûbuna dair tasavvur oluşturmada önemli veriler sağlamaktadır. Hz. Mûsâ’nın İsrâiloğulları ile kurduğu iletişimi ve yüce Allah'ın bu kavme seslenmesini ihtiva eden iki farklı âyet gurubunun ele alınacağı bu çalışmada hem klasik hem de çağdaş tefsir ve ulûmü'l-Kur'ân kaynaklarına başvurularak Kur'ân'ın ferdi iletişim üslûbunun kısmen de olsa ortaya konulması

olmayacağını mütekellim olan yüce Allah haber vermektedir. Bkz. el-Kıyâme 75/16-19.

8 Hüseyin b. Mufaddal Râğıb el-İsfehânî, Mukaddimetu câmi'i't-tefâsîr, thk. Ahmed Hasan Ferhat (Kuveyt: Dâru'd-Dave, 1984), 42-43.

9 İsfehânî, Mukaddimetu câmi'i't-tefâsîr, 39.

10 Süleyman Gezer, Sözlü Kültürden Yazılı Kültüre Kur'an, (Ankara: Ankara Okulu Yayınları, 2015), 249.

11 "Ümmi kelimesi, salt bireysel okuma yazma kabiliyetinin yoksunluğundan daha ziyade toplumsal olarak yazılı bir tarihe, kültüre ve medeniyete sahip olmamayı; aksine sözlü rivayetlere dayalı bir iletişim ve tarihe sahip olduklarını göstermektedir." Necmettin Gökkır, Kur'an Dilinin Sosyo-Kültürel Bağlamı, (İstanbul: Marmara Üniversitesi İlahiyat Fakültesi Vakfı Yayınları (İFAV), 2014) 62-63. Cahiliye ümmiliği ile ilgili daha ayrıntılı bilgi için bk. Cevâd Ali, el-Mufassal fi târîhi'l-Arab kable'l-İslâm (Beyrut: Dâru's-Sâkî, 1422/2001), XV/ 91.

12 Cevâd Ali, el-Mufassal fî târîhi'l-Arab kable'l-İslâm, XVI/408-410.

13 Süleyman Gezer, Sözlü Kültürden Yazll Kültüre Kur'an, 69-88; Celalettin Divlekci, Anlam-Üslûp Illişkisi Bağlamında Kur'an'ın Üslûp Analizi (Fâtiha Suresi Örneklemesi), (Ankara: Ankara Üniversitesi, Sosyal Bilimler Enstitüsü, Doktora Tezi, 2009), 309-310.

14 Ömer Faruk Harman, "İsrâil (Benî İsrâil)", Türkiye Diyanet Vakfi İslâm Ansiklopedisi (İstanbul: TDV Yayınları, 2001), XXIII/193-195. 
amaçlanmıştır. ${ }^{15}$ Aynı zamanda Kur'ân'ın üslûbunu günümüzün iletişim normlarına onaylatma gibi anakronik bir yanılgıya düşmeden modern dönem iletişim ve psikoloji verilerinden de yardım alınmıştır. Zikredilen amaca mâtuf olarak öncelikle analiz için seçilen âyet pasajlarının anlatım bütünü belirlenmiş, sonrasında ise pasajlardaki üslûp elemanları tespit edilerek bunların Kur'ân'ın bütünüyle olan irtibatı kurulmaya çalışılmıştır. Analiz için bu iki âyet gurubunun seçilmesinin sebebi ise söz konusu âyetlerin hem İsrâiloğulları'nın karakter özelliklerini daha belirgin bir şekilde yansıtması hem de benzer diğer âyetlerdeki üslûp elemanlarını da kapsayacak şekilde daha fazla iletişim metodu barındırmasıdır.

\section{1. İSRÂILOĞULLARI'NIN BAZI ÖZELLİKLERİ}

İsrâil kelimesi Hz. Ya'kûb'un ikinci adı veya lakabı olduğu için, onun soyundan gelenlere Tevrat'ta Beney Yisrael, Kur'ân'da Benû / Benî İsrâîl (İsrâiloğulları) denilmektedir. Yehûd ise hem İsrâiloğulları'ndan etnik olarak Yahudiliğe mensup olanları hem de diğer irklardan bu dine girenleri ifade etmektedir. ${ }^{16}$

Kur'ân'da kırk bir yerde geçen Benî İsrâil terkibi, Hz. Ya'kûb'un çocukları ve onların soyundan gelenleri, Hz. Mûsâ'nın ve Hz. Îsâ'nın kavmi gibi geçmişte yaşamış insanların yanı sıra Hz. Muhammed (s.a.v.) zamanında başta Medine olmak üzere Arap yarımadasında yaşayan yahudileri de ifade etmektedir. Kur'ân-1 Kerîm'den İsrâiloğulları'na pek çok nimet ve mûcize verildiğ $1^{17}$, Firavun'un zulmünden kurtarıldıklar1 ${ }^{18}$, diğer milletlere üstün kılındıklar1 ${ }^{19}$, yüce Allah'ın birtakım emirlerin gereğini yerine getirmeleri noktasında kendilerinden söz aldığ $1^{20}$ buna mukabil onların verdikleri sözü ihlal ettikleri ${ }^{21}$, peygamberleri haksız yere katlettikleri' $^{22}$, kutsal metni tahrif edip çarpıttıkları ${ }^{23}$, cumartesi yasağını deldikleri ${ }^{24}$ ve netice itibariyle pek azı hariç Allah'ın onları lanetlediği ve kalplerini katılaştırdığ $1^{25}$ gibi İsrâiloğulları'nın karakteristik özelliklerini yansıtan detaylı bilgiler elde edilmektedir.

İsrâiloğulları'nın konumuzla ilgili en önemli özelliği “seçilmişlik doktrini”dir. Etnik bir üstünlüğe dayalı olan seçilmişlik inancı, Tanrı'nın İsrâiloğulları ile yapmış olduğu ahit çerçevesinde onları karşılıksız bir şekilde sevmesi, kutsaması ve diğer milletlere üstün kılmasını ifade etmektedir. Aynı zamanda söz konusu seçilmişlik inancı nihai bir karakterdedir. Yani İsrâiloğulları ahit kurallarını çiğnese bile ağır cezalara maruz kalmakla birlikte ahit sürmekte ve şeçilmişlik vasfi bu kavmin ayrılmaz bir meziyeti olarak devam etmektedir. ${ }^{26} \mathrm{Bu}$

15 Ferdi üslup, bir eseri diğer eserlerden ayıran nevi şahsına münhasır özelliklerdir. Bk. Divlekci, Anlam-Üslûp Illişkisi Bağlaminda Kur'an'ın Üslûp Analizi(Fâtiha Suresi Örneklemesi), 79.

16 Harman, "İsrâil (Benî İsrâil)", XXIII: 193-195.

17 Kur'ân Yolu (Erişim 13Ekim 2020), el-Bakara 2/57; el-Câsiye 45/46.

18 el-Bakara 2/50.

19 el-Bakara $2 / 47$

20 el-Mâide 5/12.

21 el-Mâide 5/70.

22 el-Bakara $2 / 61$.

3 el-Bakara 2/75.

4 el-Bakara 2/65.

5 el-Mâide 5/13.

26 Salime Leyla Gürkan, "Kur'an'a Göre Seçilmişlik Kavramı ve İsrailoğulları’nın Seçilmişliği Meselesi”, İslam Araştırmaları Dergisi 13 (2005), 35-36.

Turkish Academic Research Review - Türk Akademik Araştırmalar Dergisi 
noktada seçilmişlik inancının, İsrâiloğulları'nın gurura kapılıp ırkî üstünlük iddiasında bulunmalarına ve diğer milletleri ve insanları hakir görmelerine yol açtığını belirtmekte fayda bulunmaktadır. Çünkü iletişimin kurulabilmesi ve devam edebilmesi için tarafların birbirlerine yakınlaştığı bir düzlem gereklidir. Ancak Yahudilik inancının merkezinde yer alan "seçilmişlik" ve "kutsallık" vasıfları ayırım ve farklılık vurgusunu da beraberinde getirmektedir. Bu durum ise sağlıklı bir iletişimin önündeki önemli engellerdendir.

Kur'ân'da beş ayrı âyette İsrâiloğulları'nın alemlere üstün kılındığını belirten ifadeler yer almaktadır. ${ }^{27}$ Ancak pek çok müfessirin de belirttiği üzere bu âyetlerde yer alan üstün kılınma ifadesi ebedilik özelliği taşımayan sınırlı bir mahiyettedir. Geçmişte birçok mûcize ve hükümranlıkla desteklenmiş olan İsrâiloğulları, aynı zamanda içlerinden peygamberler çıkarılması ve kutsal kitap indirilmesi gibi kendi dönemlerinde diğer kavimlere nasip olmayan ayrıcalıklara da sahip olmuşlardır. ${ }^{28}$ Elmalılı Muhammed Hamdi (1878-1942) İsrâiloğulları'nın diğer milletlere üstün kılınmasıyla ilgili şunları söylemektedir:

"Ey Benî İsrâîl sizin vaktiyle o nimete, o fazilete nailiyetinizin sebebi, ta Hazreti İbrâhim'in Rabbına imtihan verdiği bu kelimattan ve ona olan ahd-ü vaıdden nâşi idi. Siz Hazreti Mûsâ devrinde zalim değil, belki zürriyeti İbrâhim içinde en mazlumları idiniz. Bu sayede o nimeti ilahiyeye nail olmuştunuz. Bir hayli zaman nübüvvet ve imamet unsuru olarak âlemîne tefevvuk ettiniz, lakin ıcil meselesinden itibaren zulme başladınız, git gide bütün harekatınızda bu zulüm nihayet kavminizin hasleti şamilesi oldu. Artık badema imamet İsrail evladından çıktı ve İbrâhim zürriyetinin diğer koluna geçti." 29

Elmalılı, Hz. İbrâhim'in Rabbine yaptığg duaya ${ }^{30}$ işaret ederek ortaya koyduğu bu yorumunda, İsrâiloğulları'nın başlangıçta mazlum olduklarını, bundan dolayı diğer milletlere üstün kılındıklarını daha sonra işledikleri zulümlerle üstünlük vasfını kaybettiklerini ifade etmektedir.

\section{(BAKARA HADISESI)}

2. HZ. MÛSÂ'NIN İSRÂILOĞULLARI İLE KONUŞMASI

27 el-Bakara 2/47,122; el-A'râf 7/140; ed-Duhân 44/32; el-Câsiye 45/16.

28 Ebü'l-Fidâ' İmâdüddîn İsmâîl b. Şihâbiddîn Ömer İbn Kesir, Tefsîü'l-Kur' âni'l'azîm, thk. Muhammed Hüseyin Şemseddin (Beyrut: Dâru'l-Kütübi'l-İlmiyye, 1419), I/148; Ebû Abdillâh Muhammed b. Ahmed el-Kurtûbî,el-Câmi liahkâmi'l-Kur'ân, thk. Ahmed el-Berdûnî-İbrahim Ettafiyyiş (Kahire: Dâru'lKütübi'l-Mısriyye, 1384/1964), I/376; Muhammed Reşîd Rızâ, Tefsîrü'lKur'âni'l-hakîm (Heyetu'l-Mısriyye el-âmmetü li'l-Kitab, 1990), I/252.

29 Elmalılı Muhammed Hamdi Yazır, Hak Dini Kur'ân Dili (İstanbul: Eser, 1979), $\mathrm{I} / 492$.

30 "Bir zaman Rabbi İbrahim'i bir takım emirlerle sınamış, İbrahim onların hepsini yerine getirmiş de Rabbi şöyle buyurmuştu: "Ben seni insanlara önder yapacağım. "İbrahim de, "Soyumdan da (önderler yap, ya Rabbi!)" demişti. Bunun üzerine Rabbi, "Benim ahdim (verdiğim söz) zalimleri kapsamaz" demişti." el-Bakara 2/124. 
Bakara Sûresi 67-73 âyet grubu sûreye de ismini veren bakara hadisesini ihtiva etmektedir. Olay özetle İsrâiloğulları'ndan zengin bir kişinin akrabası tarafından öldürülmesi ve onun katilinin aranmasına dayanmaktadır. Katilin bulunamaması üzerine toplumda kargaşa oluşmuş ve çözüm bulması için $\mathrm{Hz}$. Mûsâ'ya başvurmuşlardır. O da Allah'tan aldığg vahye uygun olarak bir inek kesmelerini ve bunun bir parçasıyla maktulün cesedine vurmalarını emretmiştir. Denilenin yapılması üzerine maktul dirilmiş ve kendisini öldürenin kimliğini açıklamıştır. $^{31}$

"Hani Mûsâ kavmine, "Allah size bir sığır kesmenizi emrediyor" demişti. Onlar da, "Sen bizimle eğleniyor musun?” demişlerdi.

Mûsâ, "Kendini bilmez cahillerden olmaktan Allah'a siğınırım” demişti. "Bizim için Rabbine dua et de onun nasıl bir sı̆̆ır olduğunu bize açıklasın." dediler. Mûsâ şöyle dedi: "Rabbim diyor ki: $O$, ne yaşll, ne körpe, ikisi arası bir sığırdır. Haydi emrolunduğunuz işi yapın.” Onlar, "Bizim için Rabbine dua et de, rengi neymiş? Açıklasın" dediler. Mûsâ şöyle dedi: "Rabbim diyor ki, o, sapsarl; rengi, bakanların içini açan bir sığırdır" dedi. "Bizim için Rabbine dua et de onun nasıl bir sı̆̆ır olduğunu bize açıklasın. Çünkü siğırlar, bizce, birbirlerine benzemektedir. Ama Allah dilerse elbet buluruz” dediler. Mûsâ şöyle dedi: "Rabbim diyor ki, o; çift sürmek, ekin sulamak için boyunduruğa vurulmamış, kusursuz, hiç alacası olmayan bir sığırdır”. Onlar, "İşte, şimdi tam doğrusunu bildirdin" dediler. Nihayet o sı̆̆ırı kestiler. Neredeyse bunu yapmayacaklardl. Hani, bir kimseyi öldürmüştünüz de suçu birbirinizin üstüne atmıştınız. Hâlbuki Allah gizlemekte olduğunuzu ortaya çıkaracaktı. "Sı̆̆ııın bir parçası ile öldürülene vurun" dedik. (Denileni yaptılar ve ölü dirildi.) Işste, Allah ölüleri böyle diriltir, düşünesiniz diye mûcizelerini de size böyle gösterir." 32

Müfessirlerin genel yorumu yukarıdaki âyet pasajının İsrâiloğulları'nın katı ve inatçı tabiatlarına işaret ettiği yönündedir. Fahrettin er-Râzî (ö. 606/1210), “İsrâiloğulları'nın inek kesme emrini garipsedikleri için sürekli soru sorarak durumu güçleştirdiklerini” ${ }^{33}$ söylemiş, Muhammed b. Ahmed Kurtubî (ö. 671/1273) ise “... bu durum onların inatçı yapılarını ve emre pek itaat etmediklerini göstermektedir. Eğer emre uyup da herhangi bir ineği kesmiş olsalardı, amaç hasıl olacaktı. Ancak onlar işlerini zora sokmayı istediler, Allah da onların bu isteklerini kabul ederek

31 Muhammed b. Cerîr et-Taberî, Câmi 'u'l-beyân 'an te'vîli âyi'l-Kur'ân, thk. Ahmed Muhammed Şâkir (Kahire: Müessesetü'r-Risâle, 1420/2000), II/183-184; Fahreddin er-Râzî, Mefâtîhu'l-ğayb (Beyrut: Dâru İhyâi't-Türâsi'l-Arabî, 1420), III/543.

32 el-Bakara 2/67-73.

33 Râzî, Mefâtîhu'l-ğgyb, III/543.

Turkish Academic Research Review - Türk Akademik Araştırmalar Dergisi 
işlerini zorlaştırdı. ${ }^{34}$ diyerek kavmin inatçı tutumlarıyla durumu zorlaştırdıklarını ifade etmiştir.

Muhammed Abduh (1849-1905), bu kıssanın İsrâiloğulları'nın katılıklarına ve itaatsizliklerine temas ettiğini söylemiş ve "Yüce Allah bu kıssada bize özellikle din konusunda inatçı ve yıkıcı tavır takınmanın ve muhatabı zora sokacak sorular sormanın uygun bir davranış olmadığı mesajını vermektedir.” açıklamasında bulunarak Kur'ân'ın kendine has iletişim üslûbuyla ilgili önemli noktaları vurgulamıştır. ${ }^{35}$ Muhammed Tâhir b. Âșûr (1879-1973), yukarıdaki âyet grubunun İsrâiloğulları'nın peygamberlerine saygı duymadaki gevşekliklerini, konu hakkındaki inatçı tutumlarını ve sözde (kelamda) kastedilmeyen şeyleri anlama çabalarını içerdiğini söylemiştir. ${ }^{36}$ Seyyid Kutub (1906-1966) ise bu kıssanın Yahudilerin karakteristik özelliklerini ortaya koyduğunu belirterek şunları söylemiştir: "Bu özelliklerin en başta geleni kalpleri ile yüce Allah arasındaki ilişkinin kopuk oluşudur. Aynı zamanda bu ilişki, ince şeffaflığın, gayba inanmanın, Allah'a güvenin ve peygamberlerin getirdiği mesajları onaylama güdüsünün kaynağını teşkil etmektedir. Söz konusu özelliklerin diğerleri de yükümlülükleri üstlenmekten kaçınma, çeşitli bahanelere ve mazeretlere sarılma, kalp katılığı ile dil kabalığından kaynaklanan alaycılıktır." 37

\section{1. MUHATABA SAYGI GÖSTERME}

Bakara hadisesini ele alan bu âyet grubu iletişim açısından incelendiğinde ilk göze çarpan husus, İsrâiloğulları'nın muhataplarına saygı göstermedeki eksiklikleridir. Tarafların birbirlerine karşılıklı saygı duyması etkili bir iletişimin ön koşuludur. Bireyin muhatabına saygı duyması, muhatabın ayrı ve bağımsız bir kişilik olarak algılandığı; düşünce, duygu ve eylemlerinde özgür olduğu anlamına gelmektedir. Karşısındaki kişinin kendisine saygı duyduğunu düşünen diğer taraf, doğal olarak iletişimin sağlıklı bir şekilde devam etmesi için elinden gelen gayreti ortaya koyacaktır.

İsrâiloğulları, daha önce de ifade ettiğimiz gibi benimsedikleri seçilmişlik inancıyla Allah'ın oğulları ve dostları olduklarını iddia etmişler ${ }^{38}$ ve diğer insanları hakir görmüşlerdir. İçerisinde bulundukları problemi çözmesi için bizzat kendilerinin Hz. Mûsâ'ya başvurmalarına rağmen emri garipsedikleri için ona yönelik tutumlarıyla ve yönelttikleri sorularla alayvari bir üslup sergilemişlerdir. ${ }^{39}$ Daha da ileri giderek inek kesme emri ile talep ettikleri çözüm arasında bir bağlantı kuramadıkları için Hz. Mûsâ'yı dalga geçmekle itham etmişlerdir. ${ }^{40} \mathrm{~Hz}$. Mûsâ ise tüm bu olumsuz tutumlara karşın "cahillerden olmaktan Allah'a sı̆̆ınırım" diyerekanaliz edilmesi gereken vakar dolu bir duruş ortaya koymuştur; İbn Âşûr (1879-1973) İsrâiloğulları'nın alay etme ithamına karşı Hz Mûsâ'nın “cahillerden olmaktan Allah'a sığınırım” cevabıyla ilgili “Bu cümlede mübalağalı, vurgu dolu bir ifade şekli hakimdir. Kişi ancak büyük bir hatadan kurtulmak ve ona galip gelmek istediğinde “Allah'a sığınırım” ifadesini kullanır. Bu cümlede de "Allah'a

34 Kurtubî, el-Câmi 'li-aḥkâmi’l-Kur'ân, I/448.

35 Reşîd Rıâ, Tefsîrü'l-Ḳur'âni'l-hakîm, I/287.

36 Muhammed Tâhir İbn Âşûr, et-Tahrîr ve't-tenvîr (Tunus: ed-Dârü't-Tunusiyye, 1984), I/546.

37 Seyyid Kutub, Fî zilâli'l-Kur'ân (Kâhire: Dâru'ş-Şurûk, 2003), I/77.

38 el-Mâide 5/18.

39 Kutup, Fî̀zilâli'l-Kur'ân, I/77-78.

40 Râzî, Mefâtîhu'l-ğayb, III/546. 
sığınırım” ifadesi kullanılmıștır; çünkü dalga geçmek, istihza etmek üstün ahlaklı kimselere yakışmayan, tahkir amaçlı kullanılan ve toplum içerisinde konuşma esnasında hoş karşılanmayan bir davranıştır." ${ }^{11}$ yorumunda bulunmuştur. Kurtubî (ö. 671/1273) "Hz. Mûsâ "cahillerden olmaktan Allah'a sığınırım” şeklinde cevap vermiştir. Çünkü doğruyu araştıran ve bu maksatla soru soran bir kimseye istediğinin dışında cevap vererek alay etmek cahilliktir. Hz. Mûsâ da böyle bir duruma düşmekten Allah'a sığınmıştır." "42 açıklamasında bulunarak hakikati araştırmak için iletişim kurmayı amaçlayan bir kimsenin talebini alay ederek geri çevirmenin cahillik olacağını belirtmiştir. Seyyid Kutub (1906-1966) Hz. Mûsâ’nın, sonu gelmez münakaşalara girmekten uzak durarak tatı bir üslupla, eğitimle görevli bir öğretmenin ağırbaşlılığıyla yüce Allah karşısında takınılması gereken edebe davet ederek mukabelede bulunduğunu ifade etmiştir. ${ }^{43}$

$\mathrm{Bu}$ noktada saygı ile boyun eğiciliğin ayrımının yapılması gereklidir. Çünkü bu iki kavram genellikle birbirleriyle karıştırılmaktadır. Boyun eğicilik; bireyin duygu, düşünce, inanç gibi kendine özgü unsurları yansıtamaması, hakları başkaları tarafından çiğnenince buna karşı koyamaması ve kendini savunamaması olarak tanımlanmaktadır. Saygı ise muhatabın duygu ve düşüncelerini hafife almamak anlamına gelmektedir. ${ }^{44} \mathrm{~Hz}$. Mûsâ vakur bir şekilde İsrâiloğulları'nın taleplerine saygı göstermiş, Allah'tan aldığı vahyi onlara iletmiş, yönelttikleri sorulara her seferinde tatlı bir dille cevap vermiş ancak onlara boyun eğmemiş ve hatalarını kabullenmemiştir.

İsrâiloğulları'nın takındığı alaycı üslup Hz. Mûsâ dönemi ile sınırlı değildir. Medine'de bulunan Yahudiler her firsatı Hz. Peygamber (s.a.v.) ve Müslümanlarla dalga geçme vesilesi olarak addetmiş ve tahkir edici davranışlarda bulunmaktan geri durmamıştır. Bakara Sûresi'nde Hz. Mûsâ dönemi İsrâiloğulları'ndan bahsedilirken Medineli Yahudilere hitâben "siz" diye seslenilmesi, İsrâiloğulları'nın genetik tepkilerinin pek değişmediğine işaret etmektedir. ${ }^{45}$ Son dönemlerde davranışsal genetik adıyla yapılan çalışmalarda da ortaya konulduğu gibi insanın kalıtımsal özellikleriyle davranışları arasında güçlü bir ilişki bulunmaktadır. ${ }^{46}$ Dolayısıyla Hz. Mûsâ'ya yönelik alaycı ve inkârcı bir tutum sergileyen İsrâiloğulları, Hz. Peygamber (s.a.v.) döneminde yaşasalardı muhtemelen yine aynı tepkiyi ortaya koyarlardı. ${ }^{47}$

Medine'de bulunan Yahudiler, günlük hayatta Arapça ve İbranice karışımı bir dil (Judaeo-Arabic) kullanmakta idiler. Muhtemeldir ki Hz. Peygamber (s.a.v.)'in

41 İbn Âşûr, et-Tahrîr ve't-tenvîr, I/548.

42 Kurtûbî, el-Câmi 'li-ahkâmi'l-Kur'ân, I/446.

43 Kutup, Fîzilâli'l-Kur'ân, I/78.

44 Fulya Yüksel Şahin, "İletişim Becerilerine Genel Bir Bakış", Kişilerarası İlişkiler ve Etkili Illetişim, ed. Alim Kaya, (Ankara: Pegem Akademi, 2014), 34.

45 Şihâbüddîn Mahmûd el-Âlûsî, Rûhu'l-me 'ânî fî̀ tefsîri'l-Kur'âni'l-azîm ve'sseb 'i'l-mesânî, thk. Ali Abdülbari Atıyye (Beyrut: Dâru'l-Kütübi'l-IIlmiyye, $1415 / 1994), \mathrm{I} / 244$.

46 Doğan Cüceloğlu, Insan ve Davranışı Psikolojinin Temel Kavramları (İstanbul: Remzi Kitapevi, 2015), 87-88. Hicaz Yahudileri'nin tarihi ve kökeni ile ilgili çeşitli tartışmalar yapılmakla birlikte kanaatimizce soyu İsrailoğulları'ndan gelen Hicaz Yahudileri bölgedeki Araplarla evlilik yoluyla akrabalık bağı kurmuștur. Bk. Nuh Arslantaş, Emeviler Döneminde Yahudiler (İstanbul: Gökkubbe, 2005), 30-37.

47 Mahmut Ay, Kur'an Kıssaların Siret Bağlamında Okumak-Hz. Musa Kıssası Örneği- (İstanbul: Ensar Neşriyat, 2017), 341.

Turkish Academic Research Review - Türk Akademik Araştırmalar Dergisi 
yazışmalarda Yahudilere güvenemediği için Zeyd b. Sâbit'e öğrenmesini emrettiği ve onun da çok kısa bir sürede öğrenmeyi başardığı ve kavradığı dil Yahudilerin Arapça-İbranice karışımı dilidir. ${ }^{48}$ Kelimeleri bağlamından koparmak anlamına gelen tahrif ve tağyir hasletleriyle ön plana çıkan Yahudiler, son Peygamberin kendilerinden çıkmamasının vermiş olduğu şiddetli kıskançlık ve haset duygusuyla günlük hayatta konuştukları sentez dili, Hz. Peygamber (s.a.v.) ve sahabeyle dalga geçmek için tahkir amaçlı kullanmıştır. ${ }^{49}$ Mesela Bakara Sûresi'nde yer alan "Ey iman edenler! Peygamber'e, “Bizi de dinle” (raina; kötü anlama gelebilecek söz) demeyin, "Bizi gözet" (unzurna) deyin ve dinleyin, inkâr edenlere elem verici azab

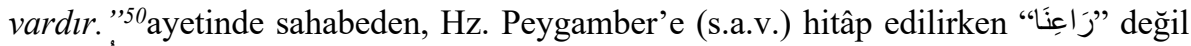
de "انظُرْنَا"ifadesinin kullanılması istenmektedir. Müslümanlar "raina” kavramını gayet halis bir niyetle Hz. Peygamber (s.a.v.) inen vahyi kendilerine tebliğ ederken "Ey Allah Rasülü! Söylediklerini anlayıncaya kadar bize müsaade et" anlamında süre talebi amaçlı kullanmıştır. Ancak söz konusu kelime Yahudilerin dilinde "Dinle, ey dinleyemez olasıca" gibi kötü bir anlama geldiğindenbu kelimeyi müminlerin ağzından duyduklarında Hz. Peygamber'le (s.a.v.) açıktandalga geçmeye başlamışlardır. "Niye bu kelimeyi kullanıyorsunuz?" diye sorulunca "Siz de peygamberinize karşı aynı kelimeyi kullanmıyor musunuz?" şeklinde cevap

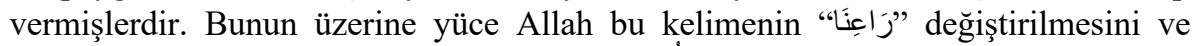
yerine aynı anlama gelen başka bir ifadenin “'انظُرْنَا kullanılmasını emretmiştir. ${ }^{51}$

Medineli Yahudilerin dil oyunlarına başvurarak Müslümanlarla sağlıklı ilişkiler kurmalarını engelleyen üstünlük anlayışına dayalı alaycı tutumları yüce Allah tarafından şu şekilde eleştirilmiştir:

"Yahudilerden öyleleri var ki, (kelimeleri yerlerinden kaydırıp)

tahrif ederek onlart anlamlarından uzaklaştırırlar. Dillerini ĕgip

bükerek ve dine saldırarak "İşittik, karşı geldik”, "İşit, işitmez

olası!" "Râ'inâ" derler. Hâlbuki onlar, "İsittik ve itaat ettik; dinle

ve bize bak" deselerdi bu kendileri için daha hayırlı olurdu. Fakat

Allah, küfürleri yüzünden kendilerini lânetlemiştir. Bu yüzden pek az

iman ederler." 52

Kelimeleri bağlamından kopartarak sözü çarpıtmak (tahrif) ve dil oyunlarına başvurarak üstünlük kurmaya kalkışmak (dili eğip bükmek) muhatabın savunma refleksleri geliştirmesine sebebiyet verir ve iletişimi kökünden zedeler. ${ }^{53}$ Nitekim Ensar'dan Sa'd b. Übade, dillerini bildiği için Yahudilerin " " aşağılama amaçlı kullandıklarının farkına varmış ve “Ey Allah’ın düşmanları! Allah'ın laneti üzerinize olsun." ${ }^{54}$ diyerek tepkisini ortaya koymuştur.

48 Nuh Arslantaş, “Hz. Peygamber'in Çağdaşı Yahudilerin Sosyo-Kültürel Hayatlarına Dair Bazı Tespitler”, ISTEM: Islâm San'at, Tarih, Edebiyat ve Mûsikîsi Dergisi VI/11 (2008), 20.

49 Gökkır, Kur'an Dilinin Sosyo-Kültürel Bağlamı, 103-104.

50 el-Bakara 2/104.

51 Ebü'l-Hasen el-Vâhidî, Esbâbü'n-nüzûl, thk. Kemal Besyûnî Zağlûl (Beyrut: Dâru'l-Kütübi'l-İlmiyye, 1411/1991), I/36; Râzî, Mefâtîhu'l-ğayb, III/634-635.

52 en-Nisâ 4/46.

53 Zillıŏlu, Iletişim Nedir?, 238-243.

54 Vâhidî, Esbâbü'n-nüzûl, I: 36. 
İsrâiloğulları'nın Hz. Mûsâ ile konuşmalarında benimsedikleri alaycı üslûbun tezahürlerinden biri de sordukları sorulardır. İnsanların birbirlerine yönelttikleri soruların niteliği, iletişimin seyrini tayin eden önemli unsurlardandır. Doğru yerde sorulan doğru sorular iletişime yeni boyutlar kazandırır ve süreci hızlandırır; yanlış zamanlama ile sorulan gereksiz sorular ise iletişimin önünün tıkadığı gibi süreci de yavaşlatır. Soru sorma işlevi ve sorunun mahiyeti muhatabı anlama gayretini somut bir şekilde ortaya koymaktadır. Açık uçlu, kapalı uçlu ve açıcı yank1 soruları gibi soru türleriyle karşı tarafa kendisinin anlaşıldığı hissi aksettirilebilir. ${ }^{55} \mathrm{Bu}$ bağlamda soruyu soran taraf hazırlık safhasında, muhatap olan taraf da dönüt verme sürecinde azami derecede ihtimam göstermelidir. İbn Abbas'tan gelen rivayette de belirtildiği gibi İsrâiloğulları, gereksiz sorular sorarak iletişim sürecini zora sokmuşlardır: "Şayet onlar herhangi bir ineği bulup kesmiş olsalardı onlar için yeterliydi. Ancak onlar kendi kendilerine işi zorlaştırdılar, Allah da onların durumunu zorlaştırd.." 56 İsrâiloğulları yönelttikleri sorularla kendileri için geniş olan bir alanı giderek daraltmışlar ve netice itibariyle de uzun uğraşılar sonunda büyük bir bedel ödeyerek belirtilen özelliklerdeki ineği bulmuşlardır. ${ }^{57} \mathrm{~Hz}$. Mûsâ ise her seferinde bıkkınlık göstermeden sorulara uygun bir şekilde cevap vermiş ve "Haydi emrolunduğunuz işi yapın." diyerek "kurulan iletişimden gözetilen faydayı (ineğin kesilerek katilin ortaya çıkması ve kaosun son bulması) yok edecek sualler sormaktan vazgeçin" uyarısında bulunmuştur. Kur'ân-1 Kerîm'de de çeşitli türleriyle soru metodu kullanılmış ve ulûmü'l-Kur'ân eserlerinde " أسلوب "الاستفهام başlığı altında müstakil bölüm şeklinde Kur'ân'ın soru sorma üslûbu irdelenmiştir. ${ }^{58}$ Aynı zamanda yüce Allah, kullarının da soru sorarken dikkatli olmalarını istemiş, lüzumsuz ve sıkıntıya düşürecek sorular sormaktan kaçınmalarını tembihlemiştir. ${ }^{59}$

\section{2. MUHATABIN DÍKKATINII ÇEKME}

Bakara kıssasında etkili iletişim açısından öne çıkan diğer bir husus da kıssanın sunuluş şeklidir. İletişimin hedeflenen amaca ulaşabilmesi için iletinin hedef kitlenin dikkatini çekecek şekilde dizayn edilmesi gereklidir. ${ }^{60}$ Kur'ân'ın geneline hakim olan ve "üslûbü'l-Kur'ân" olarak isimlendirilen metotların ve edebi sanatların pek çoğunun asli amacı muhatabın merak duygusunu harekete geçirerek dikkatini çekmek ve zihninin tamamen mesaja yoğunlaşmasını sağlamaktır. ${ }^{61}$ Söz konusu metotların önde gelenlerinden bir tanesi de "takdim ve te'hir" metodudur. "Takdim; cümle sıralamasındaki bir kelimenin herhangi bir sebepten ötürü başka bir kelimeden önce getirilmesidir. Bir şeyi takdim etmek onu başkalarının önüne koymaktır. Tehir ise, bazı özel nedenlerden ötürü önce gelmesi gereken bir öğenin sona alınmasıdır." ${ }^{2}$ Takdim ve te'hir olgusunun Kur'ân'da yer almasının çeşitli sebepleri ve amaçları bulunmakla birlikte bizim için önemli olan işlevi, muhatabın

55 A. Kadir Özer, İletişimsizlik Becerisi (İstanbul: Varlık Yayınları, 1995), 91-101.

56 Taberî, Câmi 'u'l-beyân 'an te'vîli âyi'l-Kur'ân, II/204.

57 Taberî, Câmi 'u'l-beyân 'an te vî́li âyi' '-Kur'ân, II/186-187; İbn Kesir, Tefsîrü'lKur'âni'l- 'azîm, I/191-193.

58 Bedrüddîn ez-Zerkeşî, el-Burhân fì 'ulûmi'l-Kur'ân, thk. Muhammed Ebü'l-Fazl İbrâhim, (Beyrut: Dâru İhyâi'l-Kütübi'l-Arabiyye, 1957/1376), II/327-351.

59 el-Mâide 5/101.

60 Oskay, Illetişimin $A B C$ 'si, 48.

61 Bk. Zerkeșî, el-Burhân fí 'ulumi' 'l-Kur'ân, II/383-516.

62 Ebü'l-Fazl Cemâlüddîn Muhammed b. Mükerrem İbn Manzûr, Lisânü'l- 'Arab (Beyrut: Dâru Sâdır, 1414), IV/12; XII/467-468.

Turkish Academic Research Review - Türk Akademik Araştırmalar Dergisi 
dikkatini anlatılan konuya çekmekte yardımcı olmasıdır. ${ }^{63}$ Kur'ân'daki takdim ve te'hir örnekleri herhangi bir düzensizlik ve kargaşa içermemekte bilakis Kur'ân'ın bütüncül yapısı içerisinde mesajın (kelime ve cümlelerin) muhatabın algı kanallarını harekete geçirecek şekilde düzenlendiğine işaret etmektedir; yani bağlam da dikkate alınarak (hem metin içi hem de tarihi bağlam) takdim yapılması gereken yerde takdim, te'hir yapılması gereken yerde te'hir yapıldı ğını ifade etmektedir. ${ }^{64}$

Abduh (1849-1905), kıssada yer alan takdim ve te'hir uygulamasıyla ilgili olarak şunları söylemektedir:

"Bundan önceki âyetlerde, İsrâiloğulları ile ilgili olarak, önce

kendilerine verilen nimeti, arkasından nimete küfür ve isyanla mukabelede bulunmalarını, hakettikleri cezayı, başvurdukları tevbeyi ve arkasından ilahi rahmetin kendi lehlerinde tecelli etmesi; alemlere üstün kılınmaları, kendilerinden kuvvetle söz alınması, Firavun'un zulüm ve esaretinden kurtulmaları ve arkasından kendilerine verilen nimetler ve imtihanlardan bahsedildi. Ancak tefsirini yapmakta olduğumuz bu kıssada durum farklılık arz etmektedir. Şöyle ki; bu kıssada isyan daha sonra gelen şu âyetle ifade edilmiştir: "Hani, bir kimseyi öldürmüştünüz de suçu birbirinizin üstüne atmıştınız." Arkasından, bu karışık durumdan kurtulma nimeti ve bu kurtuluşun vesilesi olmak üzere de, ineğin kesilmesi emri dile getirilmektedir: "Sığırın bir parçası ile öldürülene vurun" dedik." Olay muhatabı büyüleyecek ve meselenin perde arkasını öğrenmeye sevk edecek şekilde tasvir edilmiştir. (Zira daha önce kelamda Hz. Mûsâ'nın kendi kavmine inek kesmeleri ile ilgili bir konu geçmemişti. Söz konusu emrin bir sürpriz gibi devreye girmesi ve konu etrafında yapılan tartışma ve münakaşalar, insanda, meselenin sebebini öğrenmeye sevk edecek bir merak uyandırıyor ki, bu merak olayın sağlıklı bir şekilde takip edilmesini ve zihnin o noktada konsantre olmasını sağlamaktadır.) Çünkü Allah'ın herhangi bir topluma inek kesmelerini emretmesindeki hikmetin hemen anlaşılması mümkün değildir ve muhatabın şaşırması ve olayı öğrenmeyi çok arzulaması da gayet yerinde bir davranıştır. Özellikle de muhatap, gönülleri cezbeden ve kalpleri harekete geçiren anlatımlara alışık birisi değilse... Derim ki: Asrımızda roman diye isimlendirilen edebi türlerde de muhatabın

63 Ebû Bekr Abdülkâhir b. Abdirrahmân b. Muhammed el-Cürcânî, Delâ'ilü'l$i^{\prime} c a ̂ z$, thk. Abdulhamid Hindevi (Beyrut: Dâru'l-Kütübi'l-İlmiyye, 1422/2001), I/76-98; Zerkeşî, el-Burhân fì 'ulûmi'l-Kur'ân, III/233.

64 Müsâid b. Süleyman et-Tayyâr, Fusûl fì usûli't-tefsîr (Dâru İbni'l-Cevzi, 1423), I/143-145. 


dikkatini çekmek için böyle bir üslup kullanılmaya
çalışılmaktadır." 65

Önyargıları olan inatçı ve katı tabiatlı bir birey veya grubu iletişim ortamına dahil etmek için etkili bir stratejinin takip edilmesi gerekmektedir. Söz konusu stratejinin ilk adımı, hiç şüphesiz aktarılan mesajın muhatabın ilgisini çekecek şekilde düzenlenmesidir. Bakara kıssasının başlangıcında uygulanan takdim-te'hir metodu, hem nüzûl dönemindeki Yahudilerin hem de günümüze kadar kıssaya muhatap olanların dikkatini çekmiş ve olayın devamını öğrenmeye dair merak uyandırmıştır. Yukarıda da ifade ettiğimiz gibi Kur'ân-1 Kerîm, çeşitli metotlar vesilesiyle muhatabın idrak menfezlerine temas ederek mesajın tümünü algılaması için dinleyicide iştiyak meydana getirmeyi amaçlamıştır. Bu noktada sûre başlangıçları (فو اتح السّور) ayrı bir öneme sahiptir. Suyûtî (911), sûre başlangıçlarının iletişimdeki işlevsel konumuyla ilgili şu açıklamayı yapmıştır:

"Belâgat âlimleri; hüsnü'l-ibtidânın, sözün başlangıcında titiz bir üslûbun takip edilmesini ifade ettiğini söylemiştir. Çünkü muhatabın algı eşiğini ilk çalan odur. Eğer başlangıçtaki üslûp ilgi çekici olursa muhatap, konuşan kişiye karşı kendini bırakır, kelâmı dinler ve kavrar. Aksi takdirde -kelâmın devamı câlib-i dikkat olsa bile- dinleyici yüz çevirir. Bundan dolayı kelâma, en hoş lafızla, en ince ifadeyle, en güzel nazımla, en uygun üslûpla ve takdim-te'hir noktasındaki uyumsuzluktan kaçınarak başlamak gerekmektedir. Konuşmaya güzel bir şekilde başlamak, "berâat-i istihlâl" diye isimlendirilen özel bir bölümdür. O, hem sözün başlangıcının muhatabın durumuna uygun olmasını ifade etmekte hem de başlangıç kısmının sözün devamına işaret ettiğini ortaya koymaktadır."'66

Hurûf-1 mukattaa, sûre başlangıçlarının dikkat çekme fonksiyonu açısından en fazla öne çıkan ve mahiyeti hakkında çokça tartışma yapılan çeşididir. Subhî esSâlih (1926-1986), Kur'ân'da yirmi dokuz sûrenin başında yer alan bu harfler ile ilgili süregelen tartışmaları ortaya koyduktan sonra bu konudaki en tutarlı görüşün Reşîd Rızâ'nın görüşü olduğunu ifade ederek şunları söylemiştir:

“Reşî̉ Rıấya göre bu harfler, önce Mekke'de müşriklere yönelik sonrasında ise Medine'de Ehl-i Kitap için tenbih (uyarı) görevi üstlenmektedir. Kâfirler: “Sakın bu Kur'ân'1 dinlemeyin, okunduğunda da kuru gürültüde bulunun. Değilse ona mağlup olabilirsiniz" diyor ve böylece Kur'ân'dan yüz çevirmeyi birbirlerine tavsiye ediyorlardı. Ama Allah onların 1slahını ve faydalarını dilediği için onları susturacak ve Kur'ân'ı dinlemelerine sebep olacak alışagelmedikleri harfler indirdi. Bu harfleri duydukları zaman hayretler içerisinde "Dinleyin bakın, Muhammed'e neler geliyor" diyorlardı. Susup kulak verdiklerinde ise Kur'ân'ın etkisi altında kalıyorlardı. Böylece bu harfler Kur'ân'1 dinleyip ondan istifade etmeleri için bir vasıta oluyordu. $\mathrm{Bu}$ konudaki en tutarlı görüş Reşîd Rızâ'ya ait olduğu için onun ifadelerine yer veriyoruz:

65 Reşîd Rızâ, Tefsîrü'l-Ḳur'âni'l-hakîm, I/287.

66 Ebü'l-Fazl Celâlüddîn Abdurrahmân b. Ebî Bekr b. Muhammed el-Hudayrî esSüyûtî, el-ítkân fì ulûmi'l- Kur'ân, thk. Muhammed Ebü'l-Fadl İbrahim (Misır: el-Hey'etü'l-Misriyyetü'l-Âmme li'l-Kitâb, 1394/1974), III/ 363.

Turkish Academic Research Review - Türk Akademik Araştırmalar Dergisi 
1662 İsrâiloğullarıyla İlgili İki Âyet Grubunun (Bakara Sûresi 40-44 ve 67-73) Kur'ân'ın İletişim Üslûbu Açısından İncelenmesi

"Gayesi, ikna etme ve etkilemeyle birlikte meramı ifade edebilme olan hüsn-i beyân ve belâgattan biri de muhatabı söylenecek sözün önemi noktasında uyarmaktır. Konuşmacı diler ki; dinleyici anlatmak istediğinin tamamını anlasın ve nihai derecede etkilensin. $\mathrm{Bu}$ sebeple konuşmalarından bir şey kaçırmasın diye onu uyarır. Araplar tenbih " $h$ "sını ve istiftah edatını bunun için kullanır. Belâgat ve beyanda i'câz derecesine ulaşmış olan, ıslah ve hidayette örnek olduğu gibi bu hususlarda da örnek durumunda olması gereken Kur'ân'ın, Arapların kullanışlarına ilavelerde bulunmasında garipsenecek bir husus var mıdır?” Biz vahyin inişi anında kendisine hitap ettiği kimseler açısından bu hikmetin psikolojik vakıaya uygun düşmesi sebebiyle (inatçı ve inkârcı bir yapıda olmaları) bu görüşü tercih ettik. $\mathrm{Bu}$ harfler hayretle karşılama etkenleri olarak devam edegelmiştir. Hayretle karşılama ancak önem vermekten doğar. Önem vermeyi tahrik ise ancak uyarma ile mümkündür. İnsanların uyarılması ve dikkatlerinin çekilmesi, en güzel şekliyle, ilahi âlemin yeryüzünün kulağına fisıldadığı bu harflerle sağlanmaktadır."67

Yukarıda ele alınan yöntem ve metotlar, Kur'ân'ın iletişim üslubunda muhatabın dikkatini çekme ilkesinin önemini ortaya koymakla birlikte yüce Allah'ın insana verdiği değeri de hissettirmektedir. Muhatap konumunda olan insan ne kadar inatçı ve ön yargılı olsa da yüce Allah çeşitli metotlar kullanarak onun dikkatini çekmiş ve iletişim ortamının akamete uğramasına izin vermemiştir.

\section{SÛRESİ 40-44)}

3. YÜCE ALLAH'IN İSRÂíLOĞULLARI'NA HITÂABI (BAKARA

Bakara Sûresi'ndeki İsrâiloğulları ile ilgili bölüm, bu âyet grubuyla başlamakta ve Yüce Allah İsrâiloğulları'na ilk olarak bu âyetlerle seslenmektedir. Söz konusu özelliğinden dolayı aşağıdaki âyet pasajı, iletişimle ilgili önemli esaslar ihtiva etmektedir. Burada yüce Allah ile insanoğlu arasındaki iletişime dair şu hususun üzerinde durulmasında fayda olacağı kanaatindeyiz: Yüce Allah'ın insana yönelik hitâbının insanların kendi aralarında kurduğu iletişimden farklı olduğunu belirtmekle birlikte söz konusu hitabın iletişim başlığı altında ele alınmasının daha doğru olacağını düşünmekteyiz. Çünkü iletişim sadece sözlü olarak meydana gelmemekte, taraflar tutum ve davranışlarıyla da iletişime dahil olabilmektedirler. Yüce Allah, bazı emir ve yasaklar içeren mesajıyla insana seslenmekte; o da takındığı tavırla bu mesaja cevap vermektedir. ${ }^{68}$ Netice itibariyle de kıyamete kadar sürecek bir iletişim kurulmaktadır.

"Ey İsrâiloğulları! Size verdiğim nimeti hatırlayın. Bana verdiğiniz

sözü yerine getirin ki ben de size verdiğim sözü yerine getireyim.

Yalnız benden korkun. Elinizdeki Tevrat'ı tasdik edici olarak

67 Subhî Sâlih, Mebâhis fì ulûmi'l-Kur'ân, 244-246.

68 Toshihiko Izutsu, Kur'an'da Allah ve İnsan, çev. Süleyman Ateş (Ankara: Ankara Üniversitesi İlahiyat Fakültesi Yayınları, 1975), 131. 


\begin{abstract}
indirdiğimize (Kur'ân'a) iman edin. Onu inkâr edenlerin ilki olmayın. Âyetlerimi az bir karşılı̆̆a değişmeyin ve bana karşı gelmekten sakının. Hakkı bâtılla karıştırıp da bile bile hakkı gizlemeyin. Namazı kılın, zekâtı verin. Rükû edenlerle birlikte siz de rükû edin. Siz Kitab'ı (Tevrat'ı) okuyup durduğunuz halde, kendinizi unutup başkalarına iyiliği mi emrediyorsunuz? (Yaptığınızın çirkinliğini) anlamıyor musunuz?"69
\end{abstract}

\title{
SUNULMASI
}

\section{1. MESAJIN MUHATABI ETKILLEYECEK ŞEKILDE}

Bu başlık bir önceki bölümde yer alan "Muhatabın Dikkatini Çekme" başlı̆ğ ile benzer konular ihtiva etmekle birlikte bu madde altında daha ziyade muhatabın psikolojik yapısını da göz önünde bulundurarak mesajın içeriğinin etkileyici bir şekilde düzenlenmesi hususu ele alınacaktır.

Yüce Allah'ın, Medineli Yahudilere ilk defa seslenirken kullandığı hitâp şekli ve vurguladığı konular (önceden verilen nimetler ve ahitleşme) İsrâiloğulların'nın tarihiyle ilgili sadece din adamlarının bildiği, nüzûl dönemindeki insanların pek çoğunun vâkıf olmadığı önemli bilgiler sunmaktadır. ${ }^{70}$ İbn Âşûr (1879-1973), İsrâiloğulları'na "Ya'kûb'un evlatları" diye seslenilmesinin ve İsrâiloğulları'nın atalarına verilen nimetlerin ve mûcizelerin hatırlatılmasının onların tarihleri hakkındaki bilgilerin fazlalığına (fazla miktarda bilgi verildiğine) delalet ettiğini söylemiştir.71 Yüce Allah, Medineli Yahudilere niçin "Ey Yahudiler" şeklinde değil de "Ey İsrâiloğulları" diye seslenmiştir? Daha önce de ifade ettiğimiz üzere, İsrâil kelimesi Hz. Ya'kûb'un lakabıdır; İsrâiloğulları ise onun soyundan gelenleri tanımlamaktadır. Yahudilik ise bir din olup tüm ırklardan bu dine girenleri kapsamaktadır. Bu bağlamda "Benî İsrâil" terkibi tarihsel bir isimlendirme olup etnik kökene işaret etmektedir. ${ }^{72}$ Böylece yüce Allah, "Ey İsrâiloğulları" diye seslenerek Medine'de bulunan Yahudilerin kendi tarihleri hakkında detaylı bilgi sahibi olduğunu hissettirmiş ve harekete geçmelerini sağlamıştır. ${ }^{73}$

İletișim kurmayı amaçlayan tarafların; birbirlerinin tarihi, kültürü ve mesajın anlamsal içeriği konusunda bilgi sahibi olmalarına "izafet çerçevesi" adı verilmektedir. ${ }^{74}$ İletişim sürecinin etkili olması bu çerçevenin genişliği ile doğru orantılıdır. Kaynak kişinin mesaj gönderirken hedef kitlenin tarihini, kültürünü, karakter yapısını ve ruh halini gözetip gözetmemesine göre iletişimin verimliliğgi değişkenlik arz etmektedir. Aynı zamanda tarafların birbirleri hakkında bilgi sahibi olmaları ve süreci bu bilgiler doğrultusunda şekillendirmeleri iletişime verilen önemin göstergesidir.

69 el-Bakara, 2/40-44.

70 Taberî, Câmi 'u'l-beyân 'an te vîli âyi'l-Kur'ân, I/554-555; İbn Kesir, Tefsîrü'lKur'âni'l- 'azîm, I/147-148; Reşîd Rızâ, Tefsîrü'l-Kur'âni'l-ḥakîm, I/240-241.

71 İbn Âşû, et-Tahrîr ve't-tenvîr, I/449.

72 İbn Âşûr, et-Tahrîr ve't-tenvîr, I/449; Gökkır, Kur'an Dilinin Sosyo-Kültürel Bağlamı, 110-114.

73 İbn Kesir, Tefsîrü'l-Kur'âni'l- 'azim, I/147

74 Oskay, İletişimin ABC'si, 31; Zıllığlu, İletişim Nedir?, 215.

Turkish Academic Research Review - Türk Akademik Araştırmalar Dergisi 


\section{2. MUHATABIN AKLINA VE KALBİNE HITAP ETME}

İnsanı duygu ve akıl bileşkesi şeklinde yaratan yüce Allah, onunla iletişim kurarken bu özelliğini dikkate almış ve mesajın içeriğini hem akla hem de kalbe hitâp edecek şekilde düzenlemiştir. ${ }^{75}$ Duygu ve akıl insanın iç benliğine açılan menfezler olup sağlıklı bir iletişimde bu kanalların etkili şekilde kullanılması ön koşullardan bir tanesidir. ${ }^{76}$ Duygular, kişilerin dikkatini belli bir noktaya yöneltmelerinden ötürü "kalk borusu" na benzetilmektedir. Kalk borusu niteliğindeki duygular, harekete geçirici özelliğinden dolayı insanlara soru sorduran, açıklığa kavuşturtan, kapasite arttırtan, öğrenmelerini sağlayan, pratiğe geçirten ve tavır aldıran bir içsel ve itici güç niteliğindedir. ${ }^{77}$ Son yıllarda duyguların kişilerarası ilişkiler üzerindeki etkisine yönelik birtakım çalışmalar yapılmış ve "duygusal zeka" kuramı ön plana çıkmıştır. Duygusal zekayı; "kendini harekete geçirebilme, aksiliklere rağmen yoluna devam edebilme, dürtüleri kontrol ederek tatmini erteleyebilme, ruh halini düzenleyebilme, sıkıntıların düşünmeyi engellemesine izin vermeme, kendini başkasının yerine koyabilme ve umut besleme" şeklinde tanımlayan Daniel Goleman ${ }^{78}$, insan tabiatını duyguların gücünden soyutlayarak anlamaya çalışmayı üzücü bir dar görüşlülük olarak nitelemektedir. ${ }^{79}$ Aynı zamanda zihni, akılcı ve duygusal diye iki bölüme ayıran Goleman, sağlıklı kararlar almak ve etkili ilişkiler kurmak için her ikisinin el ele verip uyum içerisinde hareket etmesinin gerekliliğini vurgulamıştır. ${ }^{80}$

Yukarıdaki âyet pasajında yüce Allah, Medineli Yahudilere seslenirken ilk olarak atalarına verdiği nimetleri ve buna mukabil aldığı ahde riayet etmelerini hatırlatarak onların duygusal yönlerini harekete geçirmiş ve vicdanlarına temas etmiştir. Çünkü ahde vefa gösterme ve yapılan yardıma kayıtsız kalmama, duygusal konular olup anlamlarını kalpte bulan hasletlerdir. Nitekim ayette "hatırlayın" anlamını vermek için kullanılan "الذكر” kavramının çeşitli şekilleri bulunmakla birlikte burada kalpte gerçekleştirdiği fonksiyon ön plana çıkmaktadır. ${ }^{81}$ Yüce Allah'ın aynı anlama gelen başka bir kelimeyi değil de bu kelimeyi seçmesi, muhatabın mesajı kalbiyle düşünmesini sağlamak amacıyladır.

Abduh (1849-1905); konuşmacının, karşısındaki topluluğun duygularını harekete geçirecek ve saygınlığını ihsas ettirecek bir üslûp takip etmenin, muhatapta mesajı anlamaya yönelik ilginin meydana gelmesindeki rolünü vurgulayarak şunları söylemiştir:

"Kaldı ki sen bu ihsas yani hissettirme işinin dürüst olan gayrete de yardımcı olduğunu görürsün. Çünkü dürüst ve sağlıklı bir gayret,

kişinin heva ve hevesinden, şehevi isteklerinden kaynaklanan

75 Zürkânî, Menâhilü'l-irfân fì ulûmi'l-Kur'ân, II/313-314; Fehd b. Abdurrahman er-Rûmî, Hasâisu'l-Kur'âni'l-Kerim (Riyad: Mektebetü'l-Abikân, 1997), 35.

76 Seyyid Kutup, Kur'an'da Edebî Tasvir (İstanbul: Beka Yayıncılık), 324.

77 Aslı Taylı, "Kişilerarası İlişkiler ve İletişimde Duygusal Zeka", Kişilerarası Ilişskiler ve Etkili Illetişim, 227.

78 Daniel Goleman, Duygusal Zekâ, çev. Banu Seçkin Yüksel, 33. Baskı (İstanbul: Varlık Yayınları, 1996), 62.

79 Goleman, Duygusal Zekâ, 30.

80 Goleman, Duygusal Zekâ, 57.

81 Ebû Muhammed Abdülhak b. Gâlib İbn Atiyye, el-Muharrarü'l-vecîz fî tefsiri'lKitâbi'l-Azîz, thk. Abdüsselâm Abdüşşâfi Muhammed (Beyrut: Dâru'l-Kütübi'lİlmiyye, 1422), I/133. 
hususları yenmesinde işlevsel karakterdedir. Doğrusu bir nefis eğer saygın bir varlık olduğu duygusuna erişip değerinin farkına varırsa, basit işlerden oluşan rezil durumları görür ve böylece sahip olduğu değer sayesinde rezil işlerden uzak durur, sağlıklı adımlar atar. İşte bunlar, konuşmacının amacına ulaşmasındaki (mesajının muhatapta yer etmesi) en güçlü vesilelerdir. Ayrıca yapılan konuşmanın dinleyiciyi inciten ve ona acı veren bir yönü (çeşidi) de vardır. Hatta yaraladığı da olabilmektedir. Bundan dolayı yapılan incitici ve yaralayıcı konuşma sebebiyle muhatapta mesaja yönelik nefret oluşabilmekte ve konuşmayı dinlemekten kaçınabilmektedir. Konuşmacı muhatabının saygınlığını ve değerini kendisine hissettirdiği gibi aynı zamanda uzak durulduğu takdirde onun onurunu arttıracak hususları da zikretmelidir. Mesela kişinin işlediği bir takım yanlışları sürdürmesi, giderek onları kabullenmesine sebep olur. Bu da tıpkı yaralı bir kimseyi teskin etmek için hiçbir tedavi uygulamadan yaranın üzerini basit ve geçici bir şekilde pansuman yapmaya benzer." 82

İsrâiloğulları'nın kalplerinin katılığı ile ön plana çıkan bir topluluk olduğundan daha önce bahsetmiştik. Yüce Allah, İsrâiloğulları'nın kalplerinin katılığını taşa benzetmekte hatta taştan daha kasvetli bir yapıda olduğunu haber vermektedir. ${ }^{83}$ Söz konusu âyette

"Sonra bunun ardından kalpleriniz yine katılaştı, taş gibi; hatta daha katı oldu. Çünkü taş vardır ki, içinden ırmaklar fışkırır. Taş vardır ki yarılır da içinden sular çıkar. Taş da vardır ki, Allah korkusuyla (yerinden kopup) düşer. Allah yaptıklarınızdan hiçbir zaman habersiz değildir."

ifadesiyle kendilerine bahşedilen pek çok nimete ve mûcizeye rağmen İsrâiloğulları'nın verilen mesajlara ve öğütlere duyarsız kalması ve kalplerinin donuklaşması temsili bir yol ile anlatılmaktadır. ${ }^{84}$ Kalplerin katılaşmasını ifade etmek için kullanılan "القسوة" kelimesi, toprağın kuraklaşması, çölleşmesi ve her türlü işteki kabalık ve sertlik anlamlarına gelmekte; kalbin katılaşması ile kalpten yumuşaklık, merhamet ve huşû duygularının giderilmesi kastedilmektedir. ${ }^{85}$ Ebüssuûd Efendi (ö. 982/1574), âyette dikkat çekici noktalardan biri olan "taş metaforu" ile ilgili şu yorumu yapmaktadır: "Dağların eridiği, kayaların yumuşadığ 1 Kur'ân'ın mesajına yönelik İsrâiloğulları'nın kalplerinin katılığının devam etmesi -

82 Reşîd Rı̂a, Tefsîrü'l-Kur 'âni'l-hakîm, I/251.

83 el-Bakara 2/74; el-Mâide 5/13.

84 Razî, Mefâtîhu'l-ğayb, III/555; Âlûsî, Rûhu'l-me 'ânî fî̀ tefsîri'l-Kur âni'l-aẓ̂m ve's-seb 'i'l-mesânî, I/295.

85 İbn Manzûr, Lisânü'l-Arab, XV/180-181.

Turkish Academic Research Review - Türk Akademik Araştırmalar Dergisi 
kalplerinin katıllğını giderecek pek çok olay müşahede etmelerine rağmen- taşın katıllğına benzetilerek istiare yoluyla anlatılmıştır."

Kalbi hassasiyeti dumura uğramış, rikkatini kaybetmiş ve olaylara akılmenfaat perspektifinden yaklaşan bir kişiyle iletişim kurmak için sadece duygular yeterli olmayabilmekte, akli deliller sunarak kişiyi iletişim kurmaya güdülemek gerekebilmektedir. Bireyin tek bir yönünü baz alarak sadece aklına veya duygularına hitap etmek, mesajın muhatap tarafından sağlıklı bir şekilde anlaşılmasını engelleyebilmektedir. Çünkü insan; akıl, ruh ve duygu üçgeninde girift bir yapıdadır. Ancak mizacın oluşmasında pay sahibi olan ağırlık merkezleri değişkenlik göstermektedir. Kimisi duygularının hatta tutkularının etkisi altında olayları yorumlarken kimisi de hissizlikle itham edilecek şekilde duygularını minimize edip profesyonellik olarak addettiği akılcı tutum sergileme yoluna başvurmaktadır. Şehâbeddin Âlûsî'nin (ö. 1270/1854), İsrâiloğulları'nın kalplerinin katılığından bahseden âyet hakkında "Kalp kelimesinin çoğul gelmesinin sebebi incelik ve katılıkta farklılık arz etmesidir." ${ }^{\circledR 7}$ şeklindeki yorumu da aynı gerçeğe işaret etmektedir.

Yüce Allah, geçmişte verdiği nimetleri hatırlatarak İsrâiloğulları'nın duygularını harekete geçirmekle birlikte içine düştükleri yanlışın farkına varmaları için onlara akli çıkarsama yapmalarına imkân tanıyacak deliller de sunmaktadır. Yukarıdaki âyet pasajında ilk olarak geçmişte verilen nimetler ve ahit vâkıası hatırlatılmakta daha sonra ise Tevrat ile Kur'ân arasında bağ kurularak zımnen "Eğer gerçekten Tevrat'a iman etmek istiyorsanız, Kur'ân'a da iman etmelisiniz. Çünkü Kur'ân'a iman etmek, Tevrat'a iman etmek demektir." ${ }^{88}$ mesajı verilerek hem Medineli Yahudilerin hem de tüm muhatapların akli istidlalde bulunmaları sağlanmıştır. ${ }^{89}$ Bir bakıma Medineli Yahudiler'den ellerinde bulunan Tevrat bilgisi ile Kur'ân'ın ihtiva ettiği esasları mukayese ederek Kur'ân ile Tevrat'ın aynı kaynaktan geldiği dolayısıyla Kur'ân'ın mesajını benimsemenin Tevrat'a imanın gereği olduğu düşüncesine ulaşmaları amaçlanmaktadır. Ayrıca yüce Allah, özellikle Yahudi din adamlarına yönelttiği "Siz Kitabı (Tevrat'l) okuyup durduğunuz halde, kendinizi unutup başkalarına iyiliği mi emrediyorsunuz?" sorusuyla benimsedikleri yanlış inanç ve tutumları bizzat kendilerine itiraf ettirecek bir istifham üslubu kullanarak onları kapıldıkları uykudan uyanmaya ve akli körlükten kurtulmaya davet etmiş̧tir. ${ }^{90}$ "İstifhâmü't-takrîr" adı verilen bu soru çeşidinde amaç muhataptan bir cevap almak değil, içinde bulunduğu durumu bizzat kendisine ikrar ve itiraf ettirmektir. ${ }^{91}$ "Kendinizi unutup başkalarına iyiliği mi emrediyorsunuz?" sorusunun devamında akletmeye vurgu yapan, hem sunulan ögütleri idrak edecek hem de yaptığınız çirkin işlerden sizi alıkoyacak bir aklınız yok mu? sorusu tevcih edilmiştir.92 Çünkü başkalarına iyi ve faydalı işleri emretmek onlara duyulan

86 Ebüssuûd Muhammed b. Muahammed el-İmâdî, İşâdü'l-aḳli's-selîm ilâ mezâya'l-Kitâbi'l-Kerîm (Beyrut: Dâru İhyâi't-Türâsi'l-Arabî), I/114-115.

87 Âlûsî, Rûhu'l-me 'ânî fî tefsîri'l-Kur 'âni'l-aẓ̂m ve's-seb 'i'l-mesânî, I/295.

88 Râzî, Mefâtîhu'l-ğgayb, III/483.

89 Reşîd Rizâ, Tefsîrü'l-Kur 'âni'l-hakîm, I/242.

90 İbn Kesir, Tefsîrü'l-Kur 'âni'l- 'azîm, I/151.

91 Zerkeşî, el-Burhân fî̀ 'ulumi'l-Kur'ân, II/331; Süyûtî, el-ìtkân fî ulûmi'lKur'ân, III/269.

92 Âllûsî, Rûhu'l-me 'ânîfî tefsîri’l-Kur 'âni'l-aẓ̂m ve’s-seb 'i’l-mesânî, I/250. 
şefkatin bir tezahürüdür. Kişinin başkalarına beslediği şefkati kendisi için hissetmemesi ise akılla bağdaşabilecek bir durum değildir. ${ }^{93}$

Sözlükte; "yasaklamak, men etmek, devenin ayağını bağlamak" anlamlarına gelen akıl kelimesi Kur'ân'da; hak ile bâtılı ayırt etmeye yarayan ölçüt, ${ }^{95}$ mukayeseler yapabilen, ${ }^{96}$ varlıkları ve olayları inceleyip onlar hakkında kanaat sahibi olabilen, ${ }^{97}$ bununla birlikte sinırlı sayıda bilgiye sahip olabilen ${ }^{98}$ ve çeşitli vehimler sebebiyle yanılabilen ${ }^{99}$ zihinsel bir kuvve olarak zikredilmektedir. Akıl kavramı, Kur'ân'da isim olarak değil de fiil formunda 49 yerde kullanılmıştır. ${ }^{100}$ Aynı zamanda "nazar", "tebassur", "tefakkuh", "tedebbür", "tezekkür" ve "itibar" gibi kavramlarla aklın mahiyetinden ziyade işleyişine ve fonksiyonuna işaret edilmiştir. ${ }^{101} \mathrm{Bu}$ durum aklın kişiler arası ilişkiler başta olmak üzere bireyin hayatındaki önemine ve işlevsel kullanılmasının gerekliliğine işaret etmektedir.

İletişimin nihai hedeflerinden biri muhatapta istendik davranışlar meydana gelmesini sağlamaktır. Yeni bir davranışın kazanılması için bireyin iradesinin devreye girmesi, iradenin oluşması için ise kalbin ve aklın tatmin edilmesi gereklidir. Kur'ân, pek çok âyette harekete geçirdiği aklın kalple olan ilişkisini ortaya koymuştur:102 "Yeryüzünde gezip dolaşmadılar mı ki, düşünecek kalpleri, işitecek kulakları olsun? (Dolaştılar, ama ibret almadılar). Çünkü gerçekte gözler değil, göğüslerdeki kalpler (kalp gözleri) kör olur."103 Aklın kalple olan güçlü ilişkisini ortaya koyan bu âyette ${ }^{104}$ akıl, kalbe izafe edilmiştir. Çünkü aklın ve iradenin gerçek mahalli kalptir. ${ }^{105}$ Akıl, çevresinden topladığ 1 verileri birbirleriyle irtibatlandırarak bir sonuca ulaşır ve elde ettiği bu hasılayı kalbe iletir. Kalp ise irade sergileyerek nihai kararı verir. Kalp ile akıl arasındaki bu tür ilişkiden dolayı Kur'ân'da akıl kalbe izafe edilmiş ve "kalbin akledişi” ifadesi kullanılmıştır. Bununla birlikte Kur'ân'ın ortaya koyduğu akıl-kalp diyalektiğine göre, bu ikisi çelişkili bir yapı arz etmemekte, uyum içerisinde hareket etmektedir. ${ }^{106}$ Netice itibariyle Kur'ân, çeşitli metotlar kullanarak insanın hem duygularını harekete geçirmiş hem de basiretine nüfuz etmiştir. ${ }^{107}$ Böylece düşünme aktivitesinin kalpte

93 Ebü'l-Hasen Burhânüddîn İbrâhîm b. Ömer b. Hasen el-Bikâî, Nazmü'd-dürer fí tenâsübi'l-âyât ve's-süver (Kahire: Dâru'l-Kitabi'l-İslâmî), I/336; Elmal1l1, Hak Dini Kur'ân Dili, I/338-339.

94 Hüseyin b. Mufaddal Râğıb el-İsfehânî, el-Müfredât fí ğarîbi'l-Kur'ân, thk. Safvân Adnan ed-Davudî (Dimeşk: Dâru'l-Ḳalem, 1412), 578; İbn Manzûr, Lisânü'l-Arab, XI/458.

95 en-Nahl 16/78.

96 el-A'râf 7/191-195.

97 el-En'âm 6/40-41.

98 Âl-i İmrân 3/7.

99 el-Mülk 67/10.

100 Muhammed Fuâd Abdülbâki, el-Mu'cemü'l-müfehres li-elfâzi'l-Kur'âni'lKerîm, (Kahire: Dâru'l-Kütübi'l-Misriyye, 1364/1945), 468-469.

101 Yasin Pişgin, Kur'an'a Göre Akll ve Akllcllı̆̆n Kur'an Tefsirine Etkisi, (Ankara: Ankara Üniversitesi, Sosyal Bilimler Enstitüsü, Doktora Tezi, 2008), 34.

102 Kâf 50/37; Muhammed 47/24.

103 el-Hac 22/46.

104 İbn Atiyye, el-Muharrarü'l-vecîz fì tefsiri'l-Kitâbi'l-Azîz, IV/127.

105 Kurtûbî, el-Câmi 'li-ahkâmi' 'l-Kur'ân, XII/77.

106 el-Ahzâb 33/4.

107 Seyyid Kutup, Kur'an'da Edebî Tasvir, 325.

Turkish Academic Research Review - Türk Akademik Araştırmalar Dergisi 
tamamlandığı ideal bir aklediş süreciyle imanın muhatabın kişiliğinde yer etmesi amaçlanmıştır. ${ }^{108}$

\section{Sonuç}

İletişim, pek çok unsurun etkili olduğu sistemli yürütülmesi gereken kimi zaman ise öngörülemez ve kaçınılmaz olan kompleks bir süreçtir. Bu sürecin başarılı bir şekilde tamama erdirilebilmesi için farklı metotların ve uygulamaların devreye sokulması gerekmektedir. Çünkü iletişimin omurgasını teşkil eden insan faktörü, girift bir yapıda olup mizaç ve karakter açısından değişkenlik göstermektedir. Yumuşak huylu kimselerle iletişim kurmak daha kolayken sert bir mizaca sahip kimseyle iletişim kurmak kısmen daha zor olabilmektedir. Nüzul döneminde Kur'ân'ın muhatap kabul ettiği kitle de homojen bir görüntü arz etmemekte gerek inanç sistemi gerekse sosyo-kültürel açıdan farklı gruplar bulunmaktadır. Bu gruplardan birisi olan ve Kur'ân'da geniş yer tutan İsrâiloğulları, inatçı tutumlarıyla ve kelimeleri çarpıtmalarıyla ön plana çıkmaktadır. $\mathrm{Bu}$ bağlamda hem peygamberlerin hem de yüce Allah'in bu inanç grubuyla kurduğu iletişimi incelemek, Kur'ân'ın iletişim üslûbu hakkında fikir sahibi olabilmek için yerine getirilmesi gereken önemli bir çalışma olarak gözükmektedir.

Gerek Hz. Mûsâ gerekse yüce Allah bu kavme seslenirken onlara müstakil ve özgür bir kişilik sahibi olduklarını hissettirmiş ve bu doğrultuda iletişim kurmuşlardır. Yüce Allah'ın icbari bir şekilde değil de telkin ve uyarılarla onlara seslenmesi ve karakter dönüşümlerini bizzat kendi tercihleriyle yerine getirmelerini murad etmesi, sağlıklı bir iletişimin ancak müstakil varlıklar arasında meydana geleceğine işaret etmektedir.

Allah ve insan ontolojik açıdan iki farklı varlık olmalarına rağmen sağlıklı bir iletişim nasıl kurulmuştur? Nasr Hâmid Ebû Zeyd bu soruya "Taraflardan birinde, diğer tarafla iletişime imkân tanıyan bir dönüşüm gerçekleşmiştir. Yani ya Hz. Peygamber (s.a.v.) insan suretinden sıyrılarak melek suretine bürünmüştür ya da melek, insan suretine bürünmüştür." şeklinde cevap vermiştir. Ancak bu cevap mesajın içerik bölümüyle ve metinsel yapısıyla ilgili kısımdan sarfı nazar etmektedir. Aşkın olan Kelâm-1 İlâhî beşerin idrak seviyesine nasıl hitâp etmektedir? Kur'ân, özellikle metafizik alanla ilgili yoğun düşünce gerektiren soyut konuları temsil metodu ile somutlaştırarak bireyin idrakine sunmuştur. Böylece iletişimin önemli evrelerinden biri olan "mesajın içeriğinin düzenlenmesi ve kodlanması" safhası tamamlanarak sağlıklı bir iletişımin zemini hazırlanmıştır. Yüce Allah'ın insana yönelik hitâbının gerçek anlamda bir iletişim sayılıp sayılamayacağı da tartışılmaktadır. Çünkü yüce Allah insana bazı uyarı, emir ve tavsiyeler yöneltmekte; insanoğlu ise herhangi bir sözlü mukabelede bulunmamaktadır. Bundan dolayı Kur'ân'da Allah'ın insana hitâbının tam anlamıyla bir iletişimden daha ziyade tek taraflı bir ileti olduğu varsayılmaktadır. Ancak iletişim sadece sözlü mesajlardan ve dönütlerden ibaret değildir. Kaynaktan gönderilen mesaj muhatabı tavır almaya ve tutum sergilemeye sevk ediyorsa bu durum iletişim kavramının anlam alanına girmektedir.

Hz. Mûsâ'nın İsrâiloğullarıyla olan konuşmasında bu inanç gurubunun iletişim kurmaya yönelik samimiyetsizlikleri ve muhataba saygı duymada eksiklikleri müşahede edilmektedir. İletişimin akamete uğramadan başarılı bir şekilde sonuçlandırılması için tarafların gerçek anlamda iletişim kurmayı

108 Pişgin, Kur'an'a Göre Akll ve Akllcllığın Kur'an Tefsirine Etkisi, 56. 
amaçlamaları ve birbirlerine a'zamî ölçüde saygı duymaları gerekmektedir. İsrâiloğulları, samimiyetsizliklerinin tezahürü olarak sordukları sorularla, kendileri için geniş olan bir alanı daraltmış ve iletişimden beklenen faydanın hâsıl olmasını zora sokmuşlardır.

Kur'ân'ın iletişim üslûbunun mümeyyiz özelliklerinden biri de söze muhatabın ilgisini çekecek etkileyici bir ifade ile başlaması ve muhatabın dikkatini iletişim boyunca sürekli canlı tutmasıdır. Gerek Hz. Mûsâ'nın dinleyicide konuşmanın devamını öğrenmeye iştiyak uyandıracak bir ifade tarzıyla söze başlaması gerekse yüce Allah'ın İsrâiloğuları'na hitâp şekli Kur'ân'ın söz konusu üslûp özelliğine işaret etmektedir. İletişimin en önemli amacı olan "muhatapta istendik davranışlar meydana getirme" gayesine ulaşabilmek için sadece başlangıçta muhatabın ilgisini çekmek yeterli olmamakta; aynı zamanda mesajın içeriğinin ve sunuluş şeklinin onu etkisi altına alması gerekmektedir. Bu amaca mâtuf olarak Kur'ân, insanın karar verme mekanizması olan akıl-kalp diyalektiğine vurgu yapmış ve "düşünen kalp" terkibiyle kalbin ve duyguların kişiler arası ilişkilerdeki önemini ortaya koymuştur.

\section{Kaynakça}

Abdülbâki, Muhammed Fuâd. el-Mu 'cemü'l-müfehres li-elfâzi'l-Kur'âni'lKerîm. Kahire: Dâru'l-Kütübi'l-Mısriyye, 1364/1945.

Ali, Cevâd. el-Mufassal fî târîhi'l-Arab kable'l-İslâm. 20 Cilt. Beyrut: Dâru's-Sâkî, 1422/2001.

Âlûsî, Şihâbüddîn Mahmûd. Rûhu'l-me 'ânî fì tefsîri'l-Ḳur'âni'l-aẓ̂m ve'sseb 'i'l-mesânî. thk. Ali Abdülbari Atıyye.16 Cilt. Beyrut: Dâru'l-Kütübi'l-İlmiyye, $1415 / 1994$.

Arslantaş, Nuh. Emeviler Döneminde Yahudiler. İstanbul: Gökkubbe, 2005.

Arslantaş, Nuh. "Hz. Peygamber'in Çağdaşı Yahudilerin Sosyo-Kültürel Hayatlarına Dair Bazı Tespitler”, ISTEM: Islâm San'at, Tarih, Edebiyat ve Mûsikîsi Dergisi VI/11 (2008), 9-46.

Ay, Mahmut. Kur'an Kıssalarını Siret Bağlamında Okumak-Hz. Musa Kıssası Örneği-. İstanbul: Ensar Neşriyat, 2017.

Bikâî, Ebü'l-Hasen Burhânüddîn İbrâhîm. Nazmü'd-dürer fî tenâsübi'l-âyât ve's-süver. 22 Cilt. Kahire: Dâru'l-Kitabi'l-İslâmî, ts.

Cüceloğlu, Doğan. Insan ve Davranışı Psikolojinin Temel Kavramları. İstanbul: Remzi Kitapevi, 2015.

Cürcânî, Ebû Bekr Abdülkâhir b. Abdirrahmân. Delâ'ilü'l-i'câz. thk. Abdulhamid Hindevi. Beyrut: Dâru'l-Kütübi'l-İlmiyye, 1422/2001.

Demirci, Muhsin. Vahiy Gerçeği. İstanbul: Marmara Üniversitesi İlahiyat Fakültesi Vakfı Yayınları (İFAV), 1996.

Divlekci, Celalettin. Anlam-Üslûp İlişkisi Bağlamında Kur'an'ın Üslûp Analizi(Fâtiha Suresi Örneklemesi). Ankara: Ankara Üniversitesi, Sosyal Bilimler Enstitüsü, Doktora Tezi, 2009.

Turkish Academic Research Review - Türk Akademik Araştırmalar Dergisi 
1670 İsrâiloğullarıyla İlgili İki Âyet Grubunun (Bakara Sûresi 40-44 ve 67-73)

Kur'ân'ın İletişim Üslûbu Açısından İncelenmesi

Ebû Zeyd, Nasr Hâmid. Ilahi Hitabın Tabiatı - Metin Anlayışımız ve Kur'an İlimleri Üzerine-. çev. Mehmet Emin Maşalı. Ankara: Otto Yayınları, 2013.

Eser, 1979.

Elmalılı, Muhammed Hamdi Yazır, Hak Dini Kur'ân Dili.10 Cilt. İstanbul:

Gezer, Süleyman. Sözlü Kültürden Yazılı Kültüre Kur'an. Ankara: Ankara Okulu Yayınları, 2015.

Goleman, Daniel. Duygusal Zekâ. çev. Banu Seçkin Yüksel. 33. Bask1. İstanbul: Varlık Yayınları, 1996.

Gökkır, Necmettin. Kur'an Dilinin Sosyo-Kültürel Bağlamı. İstanbul: Marmara Üniversitesi İlahiyat Fakültesi Vakfı Yayınları (İFAV), 2014.

Gürkan, Salime Leyla. “Kur'an’a Göre Seçilmişlik Kavramı ve İsrailoğulları'nın Seçilmişliği Meselesi”, İslam Araştırmaları Dergisi 13 (2005), 2561.

Harman, Ömer Faruk. "İsrâil (Benî İsrâil)", Türkiye Diyanet Vakfi İslâm Ansiklopedisi. XXIII/193-195. İstanbul: TDV Yayınları, 2001.

Izutsu, Toshihiko. Kur'an'da Allah ve Insan, çev. Süleyman Ateş. Ankara: Ankara Üniversitesi İlahiyat Fakültesi Yayınları, 1975.

İbn Âşûr, Muhammed Tâhir. et-Tahrîr ve't-tenvîr. 30 Cilt. Tunus: ed-Dârü'tTunusiyye, 1984.

İbn Atiyye, Ebû Muhammed Abdülhak b. Gâlib. el-Muharrarü'l-vecîz fî tefsiri'l-Kitâbi'l-Azîz. thk. Abdüsselâm Abdüşşâfi Muhammed. 6 Cilt. Beyrut: Dâru'l-Kütübi'l-İlmiyye, 1422.

İbn Kesir, Ebü'l-Fidâ' İmâdüddîn İsmâîl. Tefsîrü'l-Kur'âni'l- 'azîm, thk. Muhammed Hüseyin Şemseddin. 9 Cilt. Beyrut: Dâru'l-Kütübi'l-İlmiyye, 1419.

İbn Manzûr, Ebü'l-Fazl Cemâlüddîn Muhammed. Lisânü'l- 'Arab. 15 Cilt. Beyrut: Dâru Sâdır, 1414.

İmâdî, Ebüssuûd Muhammed b. Muhammed. İşâdü'l-aḳli's-selîm ilâ mezâya'l-Kitâbi'l-Kerîm. 9 Cilt. Beyrut: Dâru İhyâi't-Türâsi'l-Arabî, ts.

İsfehânî, Hüseyin b. Mufaddal Râğıb. Mukaddimetu câmi'i't-tefâsîr. thk. Ahmed Hasan Ferhat. Kuveyt: Dâru'd-Dave, 1984.

İsfehânî, Hüseyin b. Mufaddal Râğıb. el-Müfredât fí ğarîbi’l-Kur'ân. thk. Safvân Adnan ed-Davudî. Dimeşk: Dâru'l-Kalem, 1412.

Kur’ân Yolu. Erişim 13Ekim 2020. https://kuran.diyanet.gov.tr/

Kurtûbî, Ebû Abdillâh Muhammed b. Ahmed. el-Câmi li-ahkâmi'l-Kur'ân, thk. Ahmed el-Berdûnî-İbrahim Ettafiyyiş. 20 Cilt. Kahire: Dâru'l-Kütübi'lMisriyye, 1384/1964.

Kutub, Seyyid. Fî zilâli'l-Kur'ân. 6 Cilt. Kâhire: Dâru'ş-Şurûk, 2003.

Kutub, Seyyid. Kur'an'da Edebî Tasvir. İstanbul: Beka Yayıncılık, ts.

Oskay, Ünsal. İletişimin $A B C$ 'si. İstanbul: İnkılâp Yayınları, 2016.

Özer, A. Kadir. İletişimsizlik Becerisi. İstanbul: Varlık Yayınları, 1995. 
Pişgin, Yasin. Kur'an'a Göre Akıl ve Akılcılı̆̆ın Kur'an Tefsirine Etkisi. Ankara: Ankara Üniversitesi, Sosyal Bilimler Enstitüsü, Doktora Tezi, 2008.

Râzî, Fahreddin. Mefâtîhu'l-ğgayb. 32 Cilt. Beyrut: Dâru İhyâi't-Türâsi'lArabî, 1420 .

Reşîd Rıâ, Muhammed. Tefsîrü'l-Kur'âni'l-hakîm. 12 Cilt. Heyetu'lMisriyye el-'âmmetü li'l-Kitab, 1990.

Rûmî, Fehd b. Abdurrahman. Hasâisu'l-Kur'âni'l-Kerim. Riyad: Mektebetü'lAbikân, 1997.

Sâlih, Subhî b. İbrâhîm. Mebâhis fì ulûmi'l-Kur ân. Beyrut: Dâru'l-İlmi li'lMelâyîn, 2014.

Süyûtî, Ebü'l-Fazl Celâlüddîn Abdurrahmân. el-İtkân fî ulûmi'l-Kur'ân. thk. Muhammed Ebü'l-Fadl İbrahim. 4 Cilt. Misır: el-Hey'etü'l-Misriyyetü'lÂmme li'l-Kitâb, 1394/1974.

Taberî, Muhammed b. Cerîr. Câmi 'u'l-beyân 'an te'vîli âyi'l-Kur'ân, thk. Ahmed Muhammed Şâkir. 24 Cilt. Kahire: Müessesetü’r-Risâle, 1420/2000.

Taylı, Aslı. "Kişilerarası İlişkiler ve İletişimde Duygusal Zeka", Kişilerarası Ilişsiler ve Etkili İletişim. ed. Alim Kaya. Ankara: Pegem Akademi, 2014

Tayyâr, Müsâid b. Süleyman. Fusûl fỉ usûli't-tefsîr. Dâru İbni'l-Cevzi, 1423.

Vâhidî, Ebü’l-Hasen. Esbâbü'n-nüzûl. thk. Kemal Besyûnî Zağlûl. Beyrut: Dâru'l-Kütübi'l-İlmiyye, 1411/1991.

Yüksel Şahin, Fulya. "İletişim Becerilerine Genel Bir Bakış”, Kişilerarası İlişkiler ve Etkili Illetişim. ed. Alim Kaya. Ankara: Pegem Akademi, 2014.

Zerkeşî, Bedrüddîn. el-Burhân fì 'ulûmi'l-Kur'ân. thk. Muhammed Ebü'lFazl İbrâhim. 4 Cilt. Beyrut: Dâru İhyâi'l-Kütübi'l-Arabiyye, 1957/1376.

Zıllığlu, Merih. Illetişim Nedir?. İstanbul: Cem Yayınevi , 2014.

Zürkânî, Muhammed Abdülazîm, Menâhilü'l-irfân fì ulûmi'l-Kur'ân. 2 Cilt. Matbaatu Îsâ el-Bâbî el-Halebî, ts.

Turkish Academic Research Review - Türk Akademik Araştırmalar Dergisi https://dergipark.org.tr/tr/pub/tarr 